Indian Journal of Science and Technology

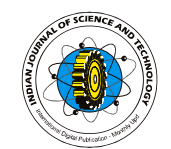

\title{
Air quality monitoring at residential areas in and around Tirupati- a well-known pilgrimage site in India
}

\author{
K. Vanadeep and M. Krishnaiah* \\ Department of Physics, Sri Venkateswara University, Tirupati, Andhra Pradesh-517502, India \\ vanadeep303@gmail.com; profkrishnaiah.m@gmail.com
}

\begin{abstract}
Tirupati is the abode of Lord Venkateswara, the richest shrine in the world that is situated in Andhra Pradesh,India. An estimated average of $1,40,000$ vehicles and about 1.5 million devotees flow every month for darshan. The principal objective of this study is to shed some light on the concentration of air pollutants to which people in the residential areas with different surroundings are exposed. This was carried out from January 2009 to December 2010. Suspended Particulate Matter (SPM), Respirable Suspended Particulate Matter $\left(\mathrm{PM}_{10}\right)$, Sulphur dioxide $\left(\mathrm{SO}_{2}\right)$, Oxides of Nitrogen $\left(\mathrm{NO}_{\mathrm{X}}\right)$ and Carbon monoxide $(\mathrm{CO})$ were estimated. SPM and RSPM $\left(\mathrm{PM}_{10}\right)$ violated the National Ambient Air Quality Standards (NAAQS). $\mathrm{CO}$ almost touched the threshold NAAQS limit. $\mathrm{SO}_{2}$ and $\mathrm{NO}_{\mathrm{x}}$ were within the recommended limits. Peak values were observed during March-May and also during winter from December-February. The concentrations of SPM in summer exceeded the concentrations in monsoon and winter by $24 \%$ each, signifying the influence of local factors on pollutant concentrations, besides the impact of meteorological parameters. The summer values of $\mathrm{PM}_{10}$ exceeded the monsoon values by $40 \%$ and winter values by $45 \% . \mathrm{SO}_{2}$ exhibited summer values that were $35 \%$ greater than the monsoon and $18 \%$ greater than the winter values. The values of $\mathrm{NO}_{x}$ during the two summers were observed to be $31 \%$ more than those recorded in the monsoon and $14 \%$ more than the respective values in winter. $\mathrm{CO}$ exhibited predominant summer values that outweighed the monsoonal values by $45 \%$ and the winter values by $39 \%$. Air quality parameters exhibited considerable relation to meteorological parameters as well as to local and anthropogenic factors. Overall, the above pollutants were found to be significantly correlated to each other. This study will help the concerned authorities to plan for better environs not only for those residents but also the pilgrims.
\end{abstract}

Keywords: Air pollution, Carbon monoxide, Sulphur dioxide, Emission, Oxides of Nitrogen, Tirupati, Meteorological dependence.

Introduction

Residential areas can be considered to be very sensitive and highly vulnerable in terms of exposure to pollution as they have higher percentages of sensitive population like infants and children, people suffering from chronic ailments, older people, pregnant and lactating women. Thus, for the better progress of a region and on the whole a nation, a clean, pollution-free and hygienic living surroundings are primarily required as they are directly related to both human health and economic productivity prospects. Table 1 shows ambient air quality standards for residential areas.

Table 1.Ambient Air Quality Standards for Residential Areas

\begin{tabular}{|l|l|}
\hline Pollutant & Concentration \\
\hline SPM & $<200 \mu \mathrm{g} / \mathrm{m} 3$ \\
\hline PM10 & $<100 \mu \mathrm{g} / \mathrm{m3}$ \\
\hline SO2 & $<80 \mu \mathrm{g} 3$ \\
\hline NOX & $<80 \mu \mathrm{g} / \mathrm{m3}$ \\
\hline CO & $<2.0 \mathrm{mg} / \mathrm{m} 3$ \\
\hline
\end{tabular}

Tirupati is the abode of the richest shrine in the world, that of Lord Venkateswara, situated in Chittoor district of Andhra Pradesh at an average altitude of 182.9 metres above sea level at $13.39^{\circ} \mathrm{N}$ latitude; $79.25^{\circ} \mathrm{E}$ longitude, is a semi-arid region with prevalent continental type of climate with three distinct seasons: Winter, Summer and Monsoon. This temple city is an internationally renowned, spiritual, educational and a buzzing commercial centre surrounded by industrial and agricultural environs.
An estimated average of $1,40,000$ vehicles (NandaKumar et al., 2008) and about 1.5 million devotees visit Tirupati every month. Cacciola et al. (2002) reported that over 0.6 billion people living in urban areas worldwide are being exposed to dangerous levels of traffic-generated air pollutants. The traffic-generated emissions are accounting for more than $50 \%$ of the total Particulate Matter (PM) emissions in the urban areas (Wrobel et al., 2000). For instance, about $80 \%$ of the PM emission is from the road traffic in London, UK (DoT, 2002). In Athens, the capital of Greece, this percentage stood at 66.5 (Economopoulou \& Economopoulos, 2002). In developed countries, Particulate Matter emissions are chiefly accountable for general health problems, reduced immunity, respiratory illness, mortality and asthma(Anderson et al., 1992; Dockery et al., 1993; Dockery \& Pope, 1994; Yang, 2002; Pope et al., 2002; Shendell \& Naeher, 2002; Wang et al., 2003). Moreover, the size distribution and the chemical composition of particles can induce health-related effects (Monn et al., 1995). About $30 \%$ of the respiratory diseases are related to personal exposure to high level ambient PM concentrations (WHO, 2000). Brandon and Hommann (1995) have observed that the ambient air pollution levels in 36 major Indian cities were exceeding the WHO standards. The International Agency of Research on Cancer (IARC,1989) declared that vehicular emissions also have potential for carcinogenicity. Traffic emissions are more harmful than compared to industrial emissions
Research article

CIndian Society for Education and Environment (iSee)
"Air quality of Tirupati"

http://www.indjst.org
Vanadeep \& Krishnaiah Indian J.Sci.Technol. 
as they are released into the atmosphere at lower heights and also they do not get sufficient scope to disperse due to surrounding density of high buildings (Safai et al., 2004). Not only the occupationally exposed people like traffic policemen, drivers, conductors and near-the-road shopkeepers, but also common residents and pedestrians are exposed to higher levels of traffic pollution in urban areas (Glovsky et al., 1997; Ye et al., 1999).

Bulk of the Indian population live in villages and also considerable number of people reside in slum areas, where extensive burning of wood and wastes take place. Particulate matters from wood burning have been shown to cause adverse health effects. The abundant organic matter and black carbon emitted upon burning wood could cause health problems ranging from slight respiratory irritation to deadly cancer, depending on the chemical composition and duration of exposure. Some of the previous studies have reported that the chemical composition of aerosols correlate with ambient air quality, particularly with atmospheric visibility reduction (Yuan et al., 2002; Lee et al., 2005; Yuan et al., 2006). Although, the use of vehicles in rural areas is very limited, the use of firewood, coal, biomass and burning of agricultural and other wastes results in the excessive generation of Carbon monoxide (CO) and Particulate Matter (PM), that is almost comparable to vehicular and industrial emissions from cities. Wood smoke may contribute significantly to the measured PM in regions with high wood burning activity. Wood smoke particles absorb more light in the Ultra Violet (UV) region than those emitted from vehicular emissions (Sandradewi, 2008). Estimated global warming caused by black carbon is next only to $\mathrm{CO}_{2}$ (Jacobson, 2001). Of the net radiation absorbed within the atmosphere, soot particles originating from wood and other biomass burning contribute about $80 \%$ to $90 \%$ (Gadhavi \& Jayaraman, 2010). Thus, the study of the effect of wood smoke particles on the concentration of Total Suspended Particulate Matter (TSPM) is also of great interest for health and regulatory purposes.

An increase in the emissions of Sulphur has been identified as the major cause of Acid precipitation (Zhao et al., 1988; Qin \& Huang, 2001). In Asia, however, due to some policies in fuel changes and other restrictions, growth of Sulphur emissions has been decelerated, but, the increase in $\mathrm{NO}_{x}$ emissions is still substantial (Streets et al., 2001). Hedin et al. had predicted that lowering of $\mathrm{pH}$ in precipitation may take place in Asia in future due to the decrease in alkaline dust owing to mobilization and urbanization (Hedin et al., 1994).

The severity of air pollution is determined largely by meteorological factors (Kukkonen et al., 2000). The discharge of contaminants in atmosphere in a particular area remains constant day by day, but, the degree of pollution may vary widely (Comrie, 1996; Wise \& Comrie, 2005). Secondary pollutants are formed when the emitted pollutants are dispersed, diluted and subjected to further reactions (Mayer, 1999). Demirci and Cuhadaroglu (2000) have reported a weak level of relation between air pollution concentrations and wind speeds. And also, Gupta et al have observed a strong inverse relation between particulates and wind speed but a weak relation with temperature (Gupta et al., 2003). On the other hand, Chan and Kwok (2001) reported a strong relationship among weather conditions that affected the concentrations of particulates. In places like Delhi, the maximum pollution loads occur during winter months, consequently causing greater exposure risk to human health (Agarwal et al., 2006). Hence, one can infer that these correlation values are site specific (Bridgman et al., 2002).

Nanda Kumar et al. (2008) have studied the air pollution levels at some important traffic junctions in Tirupati in 2003. Besides this, microbial concentrations of ambient air (Chandra Mouli et al., 2005) and major inorganic ion composition of atmospheric aerosols (Chandra Mouli et al., 2003) at Tirupati were also studied. Materials and methods

\section{Sampling sites}

Air samples were collected from the residential areas situated in and around Tirupati, Andhra Pradesh, India. All the six sampling sites are plotted in the map of Tirupati represented in Fig.1, for which the following brief descriptions are stated.

Fig. 1. Map of Tirupati showing the sampling sites- A. Railway Colony, B. Ram Nagar Quarters, C. Gandhipuram, D. Indiramma Colony, E. Rajuvaripally and F. PK Layout

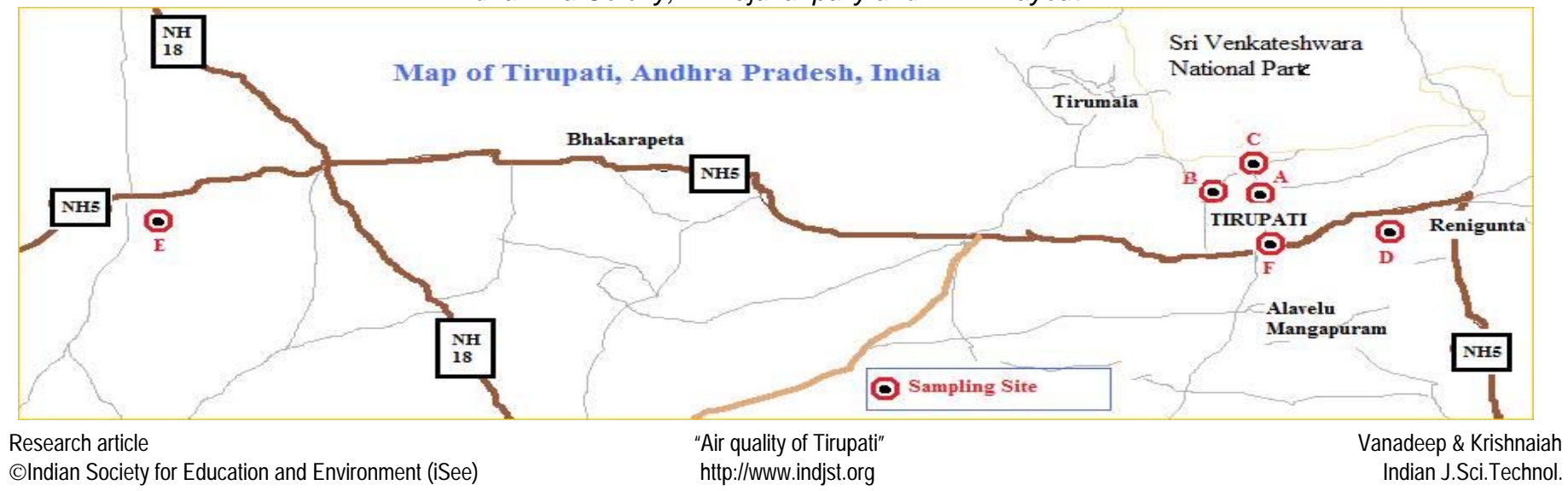


Railway Colony: represents an urban residential area, situated in the northern part of Tirupati, at a distance of about $1 \mathrm{KM}$ from the vehicular traffic on the main road. It is relatively a calm area at the heart of Tirupati.

Ram Nagar Quarters: is an urban residential area in the north-western region of Tirupati, situated adjacent to a busy traffic junction, through which hundreds of vehicles of all types (Two-wheelers, three wheelers, four wheelers; commercial and non-commercial) transit everyday on to Tirumala. One of the largest hospitals in Rayalaseema region, Sri Venkateswara Ram Narayan Ruia (S.V.R.R) hospital is also situated within $500 \mathrm{ft}$. from the junction, representing a health care zone (Sensitive area), which does not augur well for the inhabitants.

Gandhipuram is a semi-urban slum area on the southern outskirts of Tirupati, walled with rear end of Sri Padmavati Mahila Viswa Vidyalayam (S.P.M.V.V) University. Hence, this represents an institutional area with noticeable foliage where significant fire wood burning for cooking and other domestic purposes accompanied with burning of waste can be observed.

Indiramma colony is an urban slum area situated on the south-eastern outskirts of Tirupati, in the vicinity of the Industrial Estate (IE) that is encompassed with different types of major and small scale industries such as food processing units, sugar, paper industry, etc. It is located by the side of Renigunta bypass road, with considerable vehicular traffic.

Rajuvaripally is a typical rural area, situated about $30 \mathrm{~km}$. to the west of Tirupati. Surrounded by hillocks, the entire area abounds in vegetation. A quarry is situated within a few hundred feet from this village which most likely impacts nearby villages. In addition to this, brick kilns and periodical burning of agricultural wastes are also found at this site.

Pedda Kapu (P.K.) Layout is an area nested in southcentral part of Tirupati and is a conglomeration of residential buildings and commercial complexes like hotels and lodges, private travels, consultancies, etc. The most impactful factor here is Andhra Pradesh State Transport Corporation (APSRTC) Central bus station situated at a striking distance of about $200 \mathrm{ft}$. from the place. Besides, this is an extremely crowded buzzing commercial area with busy traffic junctions engaged in hectic activity, making it the most polluted region in Tirupati.

\section{Seasons in Tirupati}

Broadly, in a year, Tirupati has three distinct seasons: Summer (March-May), Monsoon (July-September), Winter (November-January). February, June and October months are considered to be transition periods with relatively stable weather conditions with sunny days. Geographically, Since Tirupati is in proximity to the coastal regions of Nellore and Chennai, this region receives prominent amounts of rainfall whenever there are cyclonic formations in the Bay of Bengal, off the coast of Chennai and coastal Nellore. Due to this, along with the South-West monsoon, the North-East monsoon also brings copious rains to this region. In the present study, analysis has been done every month for a period of two years (Jan-2009-Dec-2010) to obtain a comprehensive picture of monthly as well as seasonal variation of pollutant concentrations.

Sample collection and analysis

SPM and $\mathrm{PM}_{10}$ particulates were collected by Respirable Dust Sampler (Envirotech APM $460 \mathrm{BL}$ ). Sampling was done every month for 24 months from January 2009 to December 2010, as per the norms and regulations recommended by the Central Pollution Control Board (CPCB, 1994 \& 1998).

Air is drawn through a size-selective inlet through a glass fiber filter paper of $20.3 \times 25.4 \mathrm{~cm}(8 \times 10 \mathrm{in})$ which is used to collect $\mathrm{PM}_{10}$ (aerodynamic diameters less than $10 \mu \mathrm{m})$. The sampler was operated at an average air suction flow rate of $1.18 \mathrm{~m}^{3} \cdot \mathrm{min}^{-1}$. The flow rate of gases was 1.0 Litre Per Minute( LPM).

SPM was collected (High volume air sampler method) in the cyclone cups (sampling bottles) provided with the instrument. Particles with aerodynamic diameters less than the cut-point of the inlet (Respirable dust sampler method) are collected by the filter. The mass of these particles is determined by the difference in filter weights prior to and after sampling. The concentration of suspended particulate matter in the designated size range is calculated by dividing the weight gain of the filter by the volume of air sampled.

Calculation of volume of air sample is as follows

$\mathrm{V}=\mathrm{QT}=\left(\mathrm{F}_{\mathrm{i}}+\mathrm{F}_{\mathrm{f}}\right) / 2 \times \mathrm{t}_{\mathrm{s}} \times 10^{-6}$

Where:

$\mathrm{V}=$ Volume of air sampled in $\mathrm{m}^{3}$

$\mathrm{Q}=$ Average flow rate in $\mathrm{m}^{3} /$ minute

$\mathrm{T}=$ Total sampling time in minute

$F_{i}=$ Air flow rate before sampling, $\mathrm{cm}^{3} / \mathrm{min}$

$F_{f}=$ Air flow rate after sampling, $\mathrm{cm}^{3} / \mathrm{min}$

$\mathrm{t}_{\mathrm{s}}=$ Sampling time, $\min$

$10^{-6}=$ Conversion of $\mathrm{cm}^{3}$ to $\mathrm{m}^{3}$

Calculation of Suspended Particulate Matter (SPM) in Ambient Air

$S P M=\frac{\left(W_{f}-W_{i}\right) \times 10^{6}}{V}$

Where:

SPM = Mass concentration of suspended particles in $\mu \mathrm{g} / \mathrm{m}^{3}$

$\mathrm{Wi}=$ Initial weight of filter in $\mathrm{g}$.

$\mathrm{W}_{\mathrm{f}}=$ Final weight of filter in $\mathrm{g}$.

$\mathrm{V}=$ Volume of air sampled in $\mathrm{m}^{3}$

$10^{6}=$ Conversion of $\mathrm{g}$ to $\mu \mathrm{g}$.

Calculation of $\mathrm{PM}_{10}$ in ambient air:

$\mathrm{PM}_{10}=\frac{(\mathrm{Wp}+\mathrm{Wf})-(\mathrm{Wi}+\mathrm{Wj})}{\mathrm{V}} \times 10^{6}$

Where,
Research article

CIndian Society for Education and Environment (iSee)
"Air quality of Tirupati"

http://www.indjst.org
Vanadeep \& Krishnaiah Indian J.Sci.Technol. 
$\mathrm{Wp}=$ Weight of material that was collected on the pan including the weighing paper, gm

$\mathrm{Wj}=$ Initial weight of weighing paper, gm.

$\mathrm{Wf}=$ Weight of exposed filter, $\mathrm{gm}$

$\mathrm{Wi}=$ Tare weight of filter, gm

Same sampler was used for the sampling of $\mathrm{NO}_{x}$ and $\mathrm{SO}_{2}$ with the help of the attachments provided with the sampler. Sampling was done the same day on $24 \mathrm{hr}$. basis. For $\mathrm{SO}_{2}$ and $\mathrm{NO}_{x}$ sampling, $30 \mathrm{ml}$. of the absorbing solutions were taken in the standard impinges connected to the sampling tube. $\mathrm{SO}_{2}$ was analyzed following the modified West and Geake method, while the modified Jacob and Hochheiser method was employed in the analysis of $\mathrm{NO}_{x}$.

Calculation of $\mathrm{NO}_{2}$ concentration in ambient air

Calculation of $\mu \mathrm{g}$ of $\mathrm{NO}_{2}^{-}$per cubic meter of air is as follows:

$\mu \mathrm{g}\left(\mathrm{NO}_{2}^{-}\right) / \mathrm{m}^{3}=\frac{\mu \mathrm{g}\left(\mathrm{NO}_{2}^{-}\right) \times \mathrm{Vs}}{\operatorname{Va} \times 0.82 \times \mathrm{Vt}}$

Where:

$\mu \mathrm{g}\left(\mathrm{NO}_{2}{ }^{-}\right)=\mathrm{NO}_{2}{ }^{-}$concentration in analyzed sample

$\mathrm{Va}=$ Volume of air sample, $\mathrm{m}^{3}$

0.82 = Sampling efficiency

$D=$ Dilution factor $(D=1$ for no dilution; $D=2$ for $1: 1$ dilution).

Vs = Final volume of sampling solution

$\mathrm{Vt}=$ Aliquot taken for analysis

The $\mathrm{NO}_{2}^{-}$concentration may be calculated as ppm using : $\mathrm{ppm}\left(\mathrm{NO}_{2}{ }^{-}\right)=\left(\mu \mathrm{g}\left(\mathrm{NO}_{2}^{-}\right) / \mathrm{m}^{3}\right) \times 5.32 \times 10^{-4}$

Calculation of Concentration of $\mathrm{SO}_{2}$ in $\mu \mathrm{g} / \mathrm{m}^{3}$ in the ambient air sample is as follows:

$C\left(\mathrm{SO}_{2} \mu \mathrm{g} / \mathrm{m}^{3}\right)=\frac{\left(\mathrm{A}-\mathrm{A}_{0}\right) \times \mathrm{B} \times 10^{3}}{\mathrm{~V}}$
Where:

Vol. 4 No. 11 (Nov 2011)

ISSN: 0974- 6846

A - Sample absorbance

Ao - Reagent blank absorbance

$10^{3}$ - Conversion litres to cubic meters

B - Calibration factor, $\mu \mathrm{g} / \mathrm{absorbance}$

$\mathrm{V}$ - Volume of air sampled in liters

If desired, the concentration of sulphur dioxide may be calculated as parts per million of sulphur dioxide as follows :

$\operatorname{ppm}\left(\mathrm{SO}_{2}\right)=\mu \mathrm{g}\left(\mathrm{SO}_{2}\right) / \mathrm{m}^{3} \times 3.82 \times 10^{-4}$

For carbon monoxide (CO)

The Indicator Tube method was engaged to measure the $\mathrm{CO}$ concentration. The analyzer utilizes ambient air, which is filtered through catalyst located inside the instrument as reference gas in order to measure the concentration of $\mathrm{CO}$. The pollutants from the ambient air are sucked through a glass sampling tube at a height of about $4 \mathrm{~m}$ above the ground surface. This process uses an indicator tube containing potassium palladosulfite in which air is passed over an adsorbent until equilibrium is established between the concentration of carbon monoxide in the air and the concentration of carbon monoxide on the adsorbent. This simple and inexpensive measurement technique uses detector tubes (indicator tubes) and is based on the reaction:

$5 \mathrm{CO}+\mathrm{I}_{2} \mathrm{O}_{5} \rightarrow-\mathrm{I}_{2}+5 \mathrm{CO}_{2}$

The iodine-coloured layer in the tube corresponds in length to the carbon monoxide concentration in the sample.

The meteorological data was procured from the local weather station during the study period.

Results and discussions

Trends in monthly and seasonal variation in pollutant concentrations (2009 \& 2010)

Table 2. Trends in concentrations of pollutants in Railway Colony

\begin{tabular}{|c|c|c|c|c|c|c|c|}
\hline \multirow{2}{*}{ Pollutant } & \multirow{2}{*}{$\begin{array}{l}\text { Overall Range } \\
\left(\mu \mathrm{g} / \mathrm{m}^{3}\right)\end{array}$} & \multirow{2}{*}{$\begin{array}{c}\text { Max Variance } \\
(\%)\end{array}$} & \multirow{2}{*}{ Year } & \multicolumn{2}{|c|}{ Max Values $\left(\mu \mathrm{g} / \mathrm{m}^{3}\right)$} & \multicolumn{2}{|c|}{ Min Values $\left(\mu \mathrm{g} / \mathrm{m}^{3}\right)$} \\
\hline & & & & Month & Value & Month & Value \\
\hline \multirow{2}{*}{$\mathrm{SO}_{2}$} & \multirow{2}{*}{$3-5.6$} & \multirow{2}{*}{29} & 2009 & Jun & 5.6 & Jul & 3 \\
\hline & & & 2010 & Jun & 5.3 & Jan, Jul & 4 \\
\hline \multirow{2}{*}{$\mathrm{NO}_{\mathrm{x}}$} & \multirow{2}{*}{$8.6-13.8$} & \multirow{2}{*}{38} & 2009 & Dec & 13.6 & Mar, Apr & 8.6 \\
\hline & & & 2010 & Oct & 13.8 & Aug & 8.9 \\
\hline \multirow{2}{*}{$\mathrm{CO}$} & \multirow{2}{*}{$100-400$} & \multirow{2}{*}{75} & 2009 & Jun & 400 & $\mathrm{Dec}$ & 100 \\
\hline & & & 2010 & May & 400 & Jul, Oct & 100 \\
\hline \multirow{5}{*}{ SPM } & \multirow{5}{*}{$59-102$} & \multirow{5}{*}{42} & \multirow{2}{*}{2009} & May & 101 & Nov & 70 \\
\hline & & & & Jun & 99 & Dec & 65 \\
\hline & & & \multirow{3}{*}{2010} & Apr & 99 & Jan & 59 \\
\hline & & & & Jun & 102 & Feb & 63 \\
\hline & & & & Dec & 98 & Aug & 64 \\
\hline \multirow{4}{*}{$\mathrm{PM}_{10}$} & \multirow{4}{*}{$11.0-49$} & \multirow{4}{*}{78} & \multirow{2}{*}{2009} & May & 48 & Nov & 16 \\
\hline & & & & Jun & 41 & Dec & 11 \\
\hline & & & \multirow{2}{*}{2010} & Apr & 49 & Jan & 25 \\
\hline & & & & Jun & 45 & Jul & 26 \\
\hline
\end{tabular}

CIndian Society for Education and Environment (iSee) 
Table 3. Trends in concentrations of pollutants in Ram Nagar Quarters

\begin{tabular}{|c|c|c|c|c|c|c|c|}
\hline \multirow{2}{*}{ Pollutant } & \multirow{2}{*}{ Overall Range $\left(\mu \mathrm{g} / \mathrm{m}^{3}\right)$} & \multirow{2}{*}{ Max Variance (\%) } & \multirow{2}{*}{ Year } & \multicolumn{2}{|c|}{ Max Values $\left(\mu \mathrm{g} / \mathrm{m}^{3}\right)$} & \multicolumn{2}{|c|}{$\operatorname{Min}$ Values $\left(\mu \mathrm{g} / \mathrm{m}^{3}\right)$} \\
\hline & & & & Month & Value & Month & Value \\
\hline \multirow{2}{*}{$\mathrm{SO}_{2}$} & \multirow{2}{*}{$4.1-9.8$} & \multirow{2}{*}{58} & 2009 & May & 9.8 & Jul & 4.3 \\
\hline & & & 2010 & Dec & 7.2 & Jan,Aug & 4.1 \\
\hline \multirow{3}{*}{$\mathrm{NO} x$} & \multirow{3}{*}{$8.9-16.5$} & \multirow{3}{*}{46} & \multirow{2}{*}{2009} & May & 16.5 & Feb & 9.3 \\
\hline & & & & 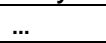 & & Jul & 9.6 \\
\hline & & & 2010 & Jun & 15.2 & Aug & 8.9 \\
\hline \multirow{2}{*}{$\mathrm{CO}$} & \multirow{2}{*}{$100-1000$} & \multirow{2}{*}{90} & 2009 & Jun & 1000 & Dec & 300 \\
\hline & & & 2010 & Sep & 800 & Jul & 100 \\
\hline \multirow{4}{*}{ SPM } & \multirow{4}{*}{$64-186$} & \multirow{4}{*}{66} & \multirow{2}{*}{2009} & May & 186 & Nov & 98 \\
\hline & & & & Jun & 182 & Dec & 86 \\
\hline & & & \multirow{2}{*}{2010} & Apr & 179 & Jan & 80 \\
\hline & & & & Nov & 142 & Aug & 64 \\
\hline \multirow{4}{*}{$\mathrm{PM}_{10}$} & \multirow{4}{*}{$15-86$} & \multirow{4}{*}{83} & \multirow{2}{*}{2009} & May & 79 & Jan & 32 \\
\hline & & & & & & Aug & 30 \\
\hline & & & \multirow{2}{*}{2010} & Apr & 86 & Jan & 25 \\
\hline & & & & May & 59 & Jul & 26 \\
\hline
\end{tabular}

Table 4. Trends in concentrations of pollutants in Gandhipuram

\begin{tabular}{|c|c|c|c|c|c|c|c|}
\hline \multirow{2}{*}{ Pollutant } & \multirow{2}{*}{ Overall Range $\left(\mu \mathrm{g} / \mathrm{m}^{3}\right)$} & \multirow{2}{*}{ Max Variance (\%) } & \multirow{2}{*}{ Year } & \multicolumn{2}{|c|}{ Max Values $\left(\mu \mathrm{g} / \mathrm{m}^{3}\right)$} & \multicolumn{2}{|c|}{$\operatorname{Min}$ Values $\left(\mu \mathrm{g} / \mathrm{m}^{3}\right)$} \\
\hline & & & & Month & Value & Month & Value \\
\hline \multirow{3}{*}{$\mathrm{SO}_{2}$} & \multirow{3}{*}{$4.0-8.1$} & \multirow{3}{*}{51} & 2009 & May & 8.1 & Jul & 4 \\
\hline & & & \multirow{2}{*}{2010} & May & 7.2 & Jan & 4.3 \\
\hline & & & & & & Sep & 4.2 \\
\hline \multirow{4}{*}{$\mathrm{NO} x$} & \multirow{4}{*}{$7.8-21.6$} & \multirow{4}{*}{64} & \multirow{2}{*}{2009} & Feb & 12.6 & Apr & 7.8 \\
\hline & & & & & & Nov & 8.1 \\
\hline & & & \multirow{2}{*}{2010} & May, Jun & 21.6 & Dec & 9.3 \\
\hline & & & & Oct & 21.3 & & \\
\hline \multirow{2}{*}{$\mathrm{CO}$} & \multirow{2}{*}{$200-700$} & \multirow{2}{*}{71} & 2009 & May & 600 & $\mathrm{Dec}$ & 200 \\
\hline & & & 2010 & Apr, May & 700 & $\mathrm{Dec}$ & 200 \\
\hline \multirow{4}{*}{ SPM } & \multirow{4}{*}{$39-136$} & \multirow{4}{*}{71} & \multirow{2}{*}{2009} & May & 136 & Nov & 48 \\
\hline & & & & & & $\overline{D e c}$ & 39 \\
\hline & & & \multirow{2}{*}{2010} & Apr & 135 & Jan, Aug & 58 \\
\hline & & & & & & Oct & 52 \\
\hline \multirow{4}{*}{$\mathrm{PM}_{10}$} & \multirow{4}{*}{$10.0-63$} & \multirow{4}{*}{84} & \multirow{2}{*}{2009} & May & 63 & Oct & 18 \\
\hline & & & & & & $\mathrm{Dec}$ & 10 \\
\hline & & & \multirow[b]{2}{*}{2010} & Apr & 61 & Jan & 22 \\
\hline & & & & Jun & 54 & Oct & 25 \\
\hline
\end{tabular}

Table 5. Trends in concentrations of pollutants in Indiramma Colony

\begin{tabular}{|c|c|c|c|c|c|c|c|}
\hline \multirow{2}{*}{ Pollutant } & \multirow{2}{*}{ Overall Range $\left(\mu \mathrm{g} / \mathrm{m}^{3}\right)$} & \multirow{2}{*}{ Max Variance (\%) } & \multirow{2}{*}{ Year } & \multicolumn{2}{|c|}{ Max Values $\left(\mu \mathrm{g} / \mathrm{m}^{3}\right)$} & \multicolumn{2}{|c|}{$\operatorname{Min}$ Values $\left(\mu \mathrm{g} / \mathrm{m}^{3}\right)$} \\
\hline & & & & Month & Value & Month & Value \\
\hline \multirow{2}{*}{$\mathrm{SO}_{2}$} & \multirow{2}{*}{$5.3-13.2$} & \multirow{2}{*}{60} & 2009 & May & 13.2 & Jul & 5.3 \\
\hline & & & 2010 & Jun & 11.6 & Jul & 6.9 \\
\hline \multirow{3}{*}{$\mathrm{NO}_{x}$} & \multirow{3}{*}{$12.4-29.3$} & \multirow{3}{*}{58} & \multirow{2}{*}{2009} & May & 26.8 & Feb & 12.6 \\
\hline & & & & & & Jul & 12.4 \\
\hline & & & 2010 & Jun & 29.3 & Jul & 13.6 \\
\hline \multirow{2}{*}{$\mathrm{CO}$} & \multirow{2}{*}{$300-1100$} & \multirow{2}{*}{73} & 2009 & Jun & 1100 & Dec & 300 \\
\hline & & & 2010 & Apr & 1100 & Jan & 400 \\
\hline \multirow{4}{*}{ SPM } & \multirow{4}{*}{$95-166$} & \multirow{4}{*}{43} & \multirow{2}{*}{2009} & May & 159 & Dec & 95 \\
\hline & & & & Jun & 152 & $\ldots$ & $\ldots$ \\
\hline & & & \multirow{2}{*}{2010} & Jun & 166 & Jan & 99 \\
\hline & & & & & & Feb & 106 \\
\hline \multirow{4}{*}{$\mathrm{PM}_{10}$} & \multirow{4}{*}{$19-72$} & \multirow{4}{*}{74} & \multirow{2}{*}{2009} & May & 68 & Aug & 23 \\
\hline & & & & & & Dec & 19 \\
\hline & & & \multirow{2}{*}{2010} & Mar & 68 & Jan & 39 \\
\hline & & & & Jun & 72 & Aug & 36 \\
\hline
\end{tabular}


Table 6. Trends in concentrations of pollutants in Rajuvaripally

\begin{tabular}{|c|c|c|c|c|c|c|c|}
\hline \multirow{2}{*}{ Pollutant } & \multirow{2}{*}{ Overall Range $\left(\mu \mathrm{g} / \mathrm{m}^{3}\right)$} & \multirow{2}{*}{$\begin{array}{c}\text { Max Variance } \\
(\%)\end{array}$} & \multirow{2}{*}{ Year } & \multicolumn{2}{|c|}{ Max Values $\left(\mu \mathrm{g} / \mathrm{m}^{3}\right)$} & \multicolumn{2}{|c|}{ Min Values $\left(\mu \mathrm{g} / \mathrm{m}^{3}\right)$} \\
\hline & & & & Month & Value & Month & Value \\
\hline \multirow{2}{*}{$\mathrm{SO}_{2}$} & \multirow{2}{*}{$4.1-6.6$} & \multirow{2}{*}{38} & 2009 & May & 6.6 & Mar, Apr & 4.1 \\
\hline & & & 2010 & Nov & 6.3 & Jan, Jul & 4.1 \\
\hline \multirow{2}{*}{$\mathrm{NO}_{x}$} & \multirow{2}{*}{$3.8-22.4$} & \multirow{2}{*}{83} & 2009 & Feb, Dec & 9.3 & Jul & 3.8 \\
\hline & & & 2010 & Jun & 22.4 & Jul & 6.9 \\
\hline \multirow{2}{*}{$\mathrm{CO}$} & \multirow{2}{*}{$200-600$} & \multirow{2}{*}{67} & 2009 & Jun & 600 & $\begin{array}{l}\text { Jan, Mar, Apr, Aug, } \\
\text { Nov, Dec }\end{array}$ & 200 \\
\hline & & & 2010 & Jun & 600 & $\begin{array}{l}\text { Feb, Jul, Aug, } \\
\text { Sep, Nov, Dec }\end{array}$ & 200 \\
\hline \multirow{4}{*}{ SPM } & \multirow{4}{*}{$50-92$} & \multirow{4}{*}{46} & \multirow{2}{*}{2009} & May & 88 & Aug & 51 \\
\hline & & & & Jun & 82 & Dec & 50 \\
\hline & & & \multirow{2}{*}{2010} & May & 88 & Aug & 46 \\
\hline & & & & Jun & 92 & $\ldots$ & $\ldots$ \\
\hline \multirow{4}{*}{$\mathrm{PM}_{10}$} & \multirow{4}{*}{$13-46$} & \multirow{4}{*}{72} & \multirow{2}{*}{2009} & Mar, May & 39 & Oct & 16 \\
\hline & & & & $\ldots$ & $\ldots$ & Dec & 13 \\
\hline & & & \multirow{2}{*}{2010} & May & 43 & Aug & 20 \\
\hline & & & & Jun & 46 & Dec & 21 \\
\hline
\end{tabular}

Table 7. Trends in concentrations of pollutants in P.K. Layout

\begin{tabular}{|c|c|c|c|c|c|c|c|}
\hline \multirow{2}{*}{ Pollutant } & \multirow{2}{*}{ Overall Range $\left(\mu \mathrm{g} / \mathrm{m}^{3}\right)$} & \multirow{2}{*}{$\begin{array}{c}\text { Max Variance } \\
(\%)\end{array}$} & \multirow{2}{*}{ Year } & \multicolumn{2}{|c|}{ Max Values $\left(\mu \mathrm{g} / \mathrm{m}^{3}\right)$} & \multicolumn{2}{|c|}{ Min Values $\left(\mu \mathrm{g} / \mathrm{m}^{3}\right)$} \\
\hline & & & & Month & Value & Month & Value \\
\hline \multirow{3}{*}{$\mathrm{SO}_{2}$} & \multirow{3}{*}{$8.3-20.1$} & \multirow{3}{*}{59} & 2009 & May & 15.9 & Jul & 8.3 \\
\hline & & & \multirow{2}{*}{2010} & Jun & 20.1 & Jul & 9.9 \\
\hline & & & & $\ldots$ & $\ldots$ & Nov & 8.9 \\
\hline \multirow{2}{*}{$\mathrm{NO} x$} & \multirow{2}{*}{$11.2-31.6$} & \multirow{2}{*}{65} & 2009 & Dec & 29.8 & Jul & 11.2 \\
\hline & & & 2010 & Jun & 31.6 & Jul, Oct & 19.3 \\
\hline \multirow{2}{*}{$\mathrm{CO}$} & \multirow{2}{*}{$600-1600$} & \multirow{2}{*}{63} & 2009 & Jun & 1600 & $\mathrm{Dec}$ & 600 \\
\hline & & & 2010 & Jun & 1500 & Jan & 700 \\
\hline \multirow{4}{*}{ SPM } & \multirow{4}{*}{$121-342$} & \multirow{4}{*}{65} & \multirow{2}{*}{2009} & May & 334 & Dec & 151 \\
\hline & & & & Jun & 342 & $\ldots$ & $\ldots$ \\
\hline & & & \multirow{2}{*}{2010} & Apr & 322 & Jan & 121 \\
\hline & & & & Jun & 333 & Feb & 135 \\
\hline \multirow{4}{*}{$\mathrm{PM}_{10}$} & \multirow{4}{*}{$44-126$} & \multirow{4}{*}{65} & \multirow{2}{*}{2009} & May & 120 & Nov & 44 \\
\hline & & & & Jun & 126 & $\ldots$ & $\ldots$ \\
\hline & & & \multirow{2}{*}{2010} & Apr & 113 & Oct & 55 \\
\hline & & & & Jun & 116 & Dec & 50 \\
\hline
\end{tabular}


Average monthly and seasonal variation of $\mathrm{SO}_{2}, \mathrm{NO}_{\mathrm{X}}$ (predominantly $\mathrm{NO}_{2}$ ), CO, SPM and RSPM (or $\mathrm{PM}_{10}$ ) are presented graphically in Fig. 2-5.

Among the above mentioned six sampling areas, three areas (P.K.Layout, Indiramma colony and Ram nagar) showed higher pollutant concentrations (Tables 2-7) than the remaining three areas (Swetha residency, Gandhipuram and Rajuvaripally).

The SPM concentration in the first set of three regions was $18 \%-73 \%$ greater than that in the second set of three regions during summer. While during monsoon, this range was $19 \%-55 \%$ and in winter, this extended from $31 \%-51 \%$. $\mathrm{PM}_{10}$ concentration in the three relatively polluted areas exceeded the concentration in the rest of the three regions by $12 \%-63 \%$ in summer. This alternated between $20 \%$ and $58 \%$ in monsoon and during winter, this range stood at $31 \%-56 \%$.

Likewise, in the case of gases, similar trends were observed. The $\mathrm{SO}_{2}$ values during summer in the former three polluted areas mentioned above showed an increase of the order of $17 \%-69 \%$ over the latter three not so polluted areas. In monsoon, this range was observed to be $7 \%-64 \%$. And in winter, this percentage spanned from $12 \%-61 \%$. Now taking $\mathrm{NO}_{x}$ into account, during summer, the comparatively more polluted areas had $4 \%-58 \%$ more $\mathrm{NO}_{x}$ concentrations than the remaining areas. This was at $7 \%-62 \%$ during monsoon. And in winter, this was estimated to be between $23 \%$ $54 \%$. In case of CO, this was calculated to be $25 \%-64 \%$ during summer, $25 \%-75 \%$ in monsoon and $20 \%-73 \%$ during winter.

On the seasonal front, on an average, the concentration of SPM in summer exceeded the concentrations in monsoon and winter by $24 \%$ each, signifying the influence of local factors (discussed below) on the pollutant concentrations, besides the impact of the meteorological parameters. The summer values of $\mathrm{PM}_{10}$ exceeded the monsoon values by $40 \%$ and winter values by $45 \% . \mathrm{SO}_{2}$ exhibited summer values that were $35 \%$ greater than the monsoon and $18 \%$ greater than the winter values. The values of $\mathrm{NO}_{x}$ during the two summers were observed to be $31 \%$ more than those recorded in the monsoon and $14 \%$ more than the respective values in winter. The most abundant and dreadful gaseous pollutant $\mathrm{CO}$, also exhibited predominant summer values that outweighed the monsoonal values by a margin of $45 \%$ and the corresponding winter values by $39 \%$.

Fig. 2. Monthly variations of SPM and PM10 concentrations
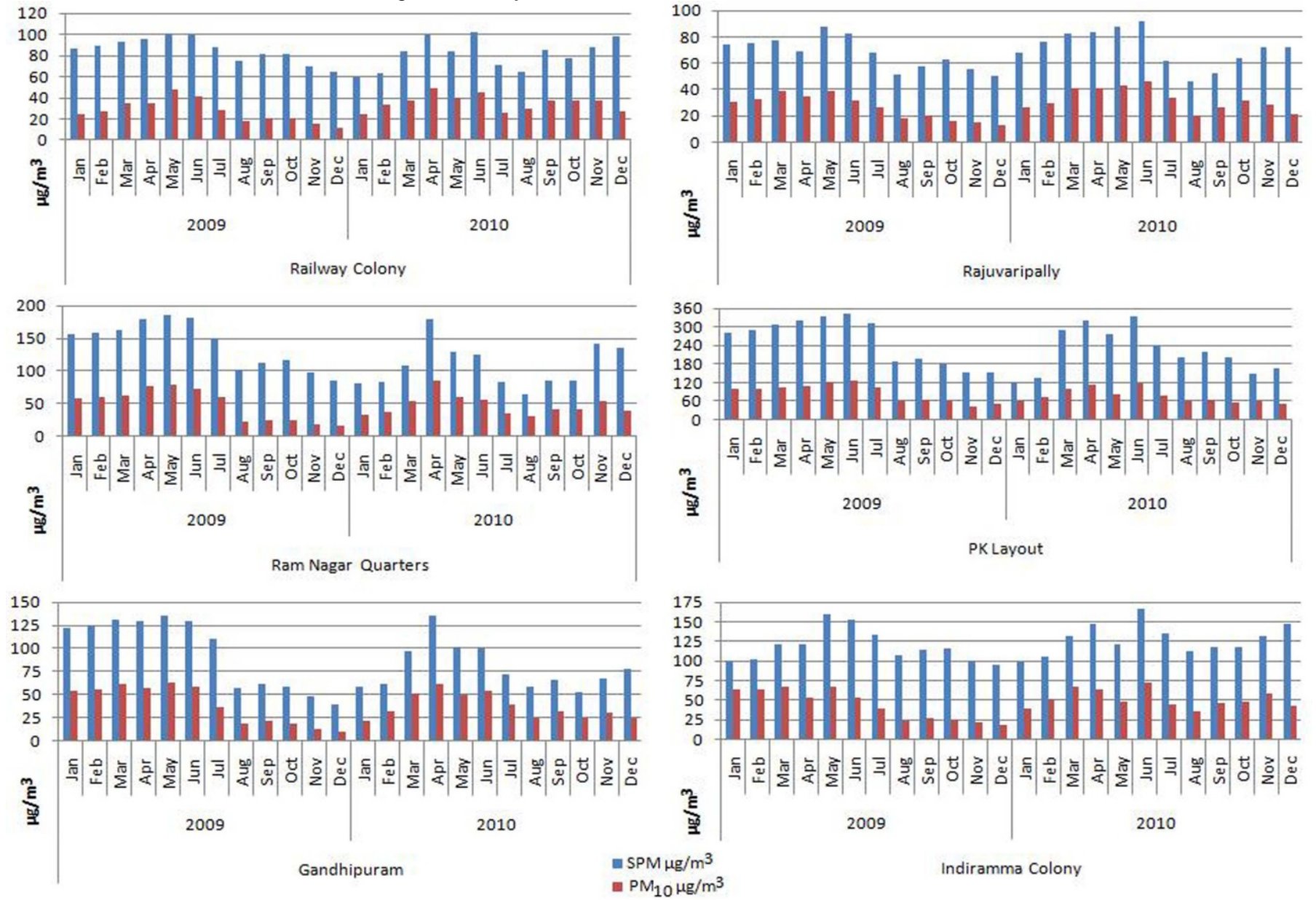
Fig. 3. Monthly variations of $\mathrm{SO}_{2}, \mathrm{NO} x$ and $\mathrm{CO}$ concentrations
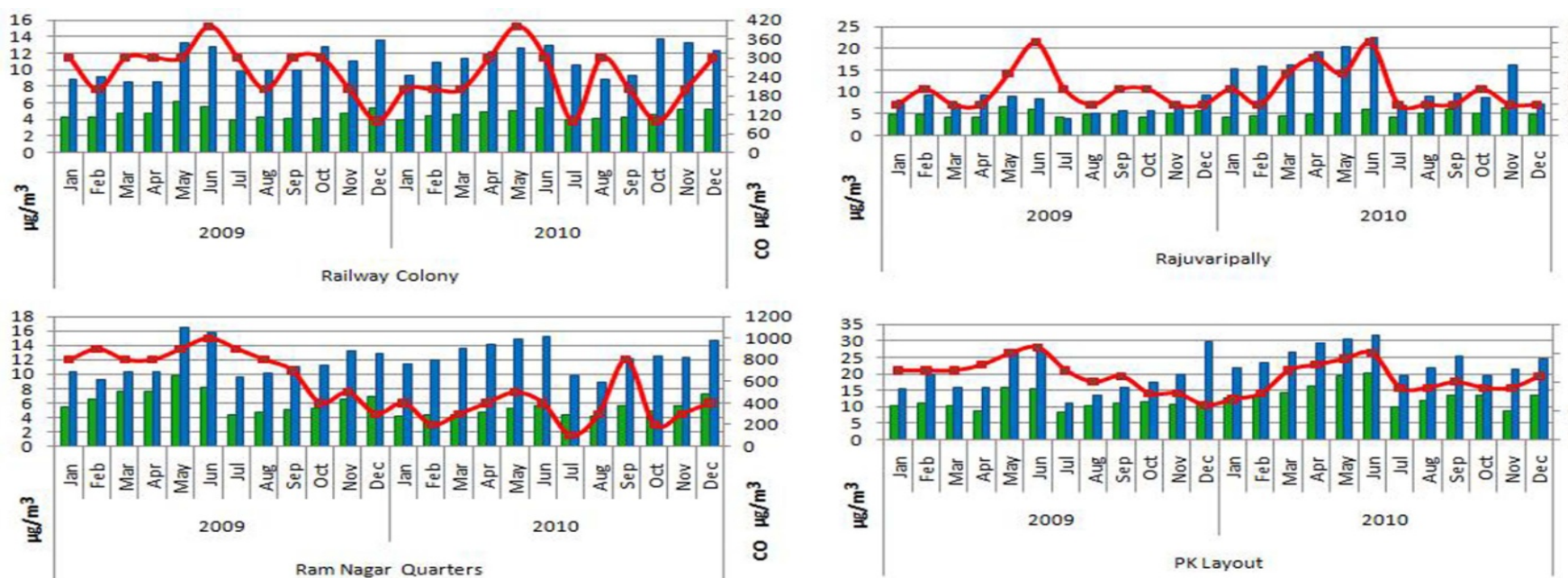

1200
1000
800
600
400
200
0
0
$\frac{3}{5}$
8
8
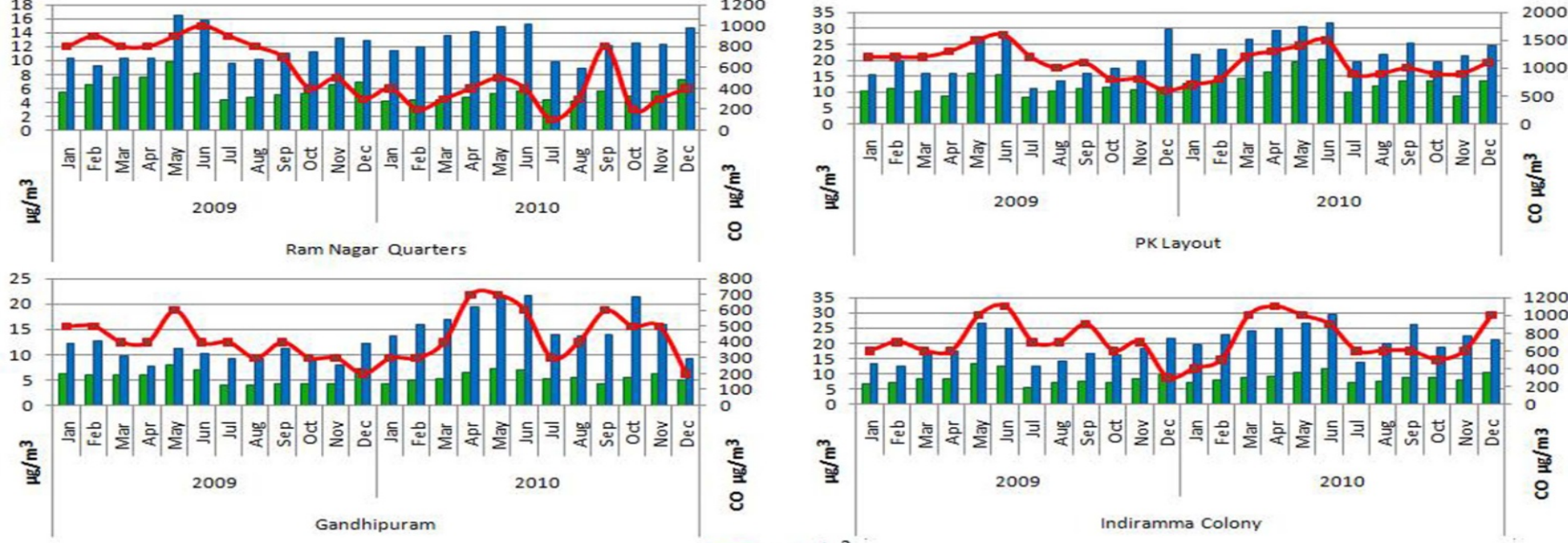

$\mathrm{SO}_{2} \mu \mathrm{gg} / \mathrm{m}^{3}$

$=-\mathrm{NO} \times \mu \mathrm{\mu g} / \mathrm{m}^{3}$

Fig. 4. Seasonal variation of SPM and $P M_{10}$ concentrations
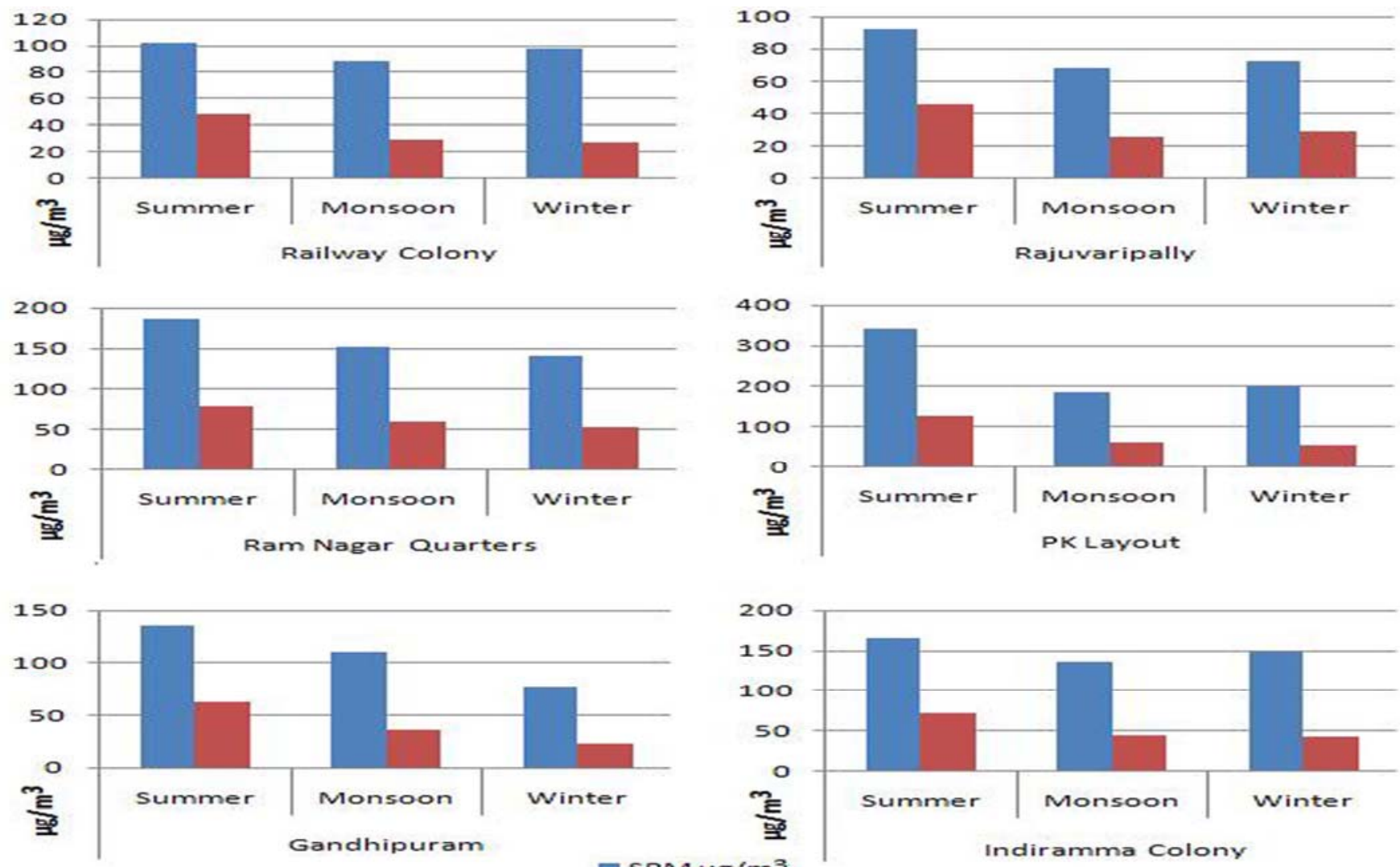
Fig. 5. Seasonal variation of $\mathrm{SO}_{2}, \mathrm{NO} x$ and $\mathrm{CO}$ concentrations
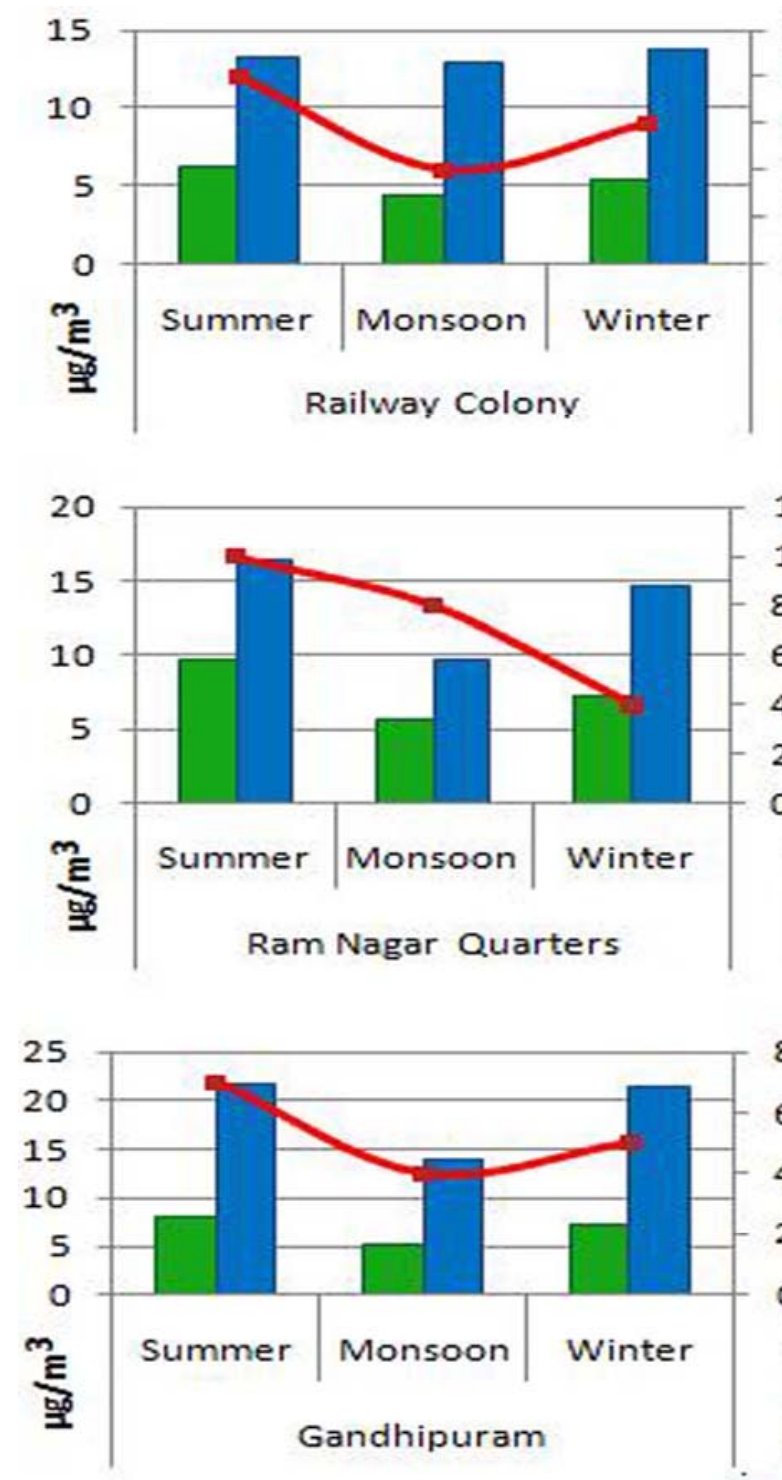

Local and anthropogenic factors

Air quality parameters exhibited considerable relation to local and anthropogenic factors. In Tirupati, summer experienced an increase in pollutant concentrations during April and May and the peak value was observed in June, which marks the transition from summer to monsoon and onset of the South-West monsoons.

Tirupati, being a world renowned pilgrim centre, unprecedented number of people from all over the country visit this place, predominantly during summer vacation literally till the end of June resulting in drastic increase in the levels of air pollution. The summer maxima owe a great deal to the local factors like tremendous increase in vehicular traffic, extensive forest fires on Tirumala hills and other nearby surrounding Research article CIndian Society for Education and Environment (iSee)

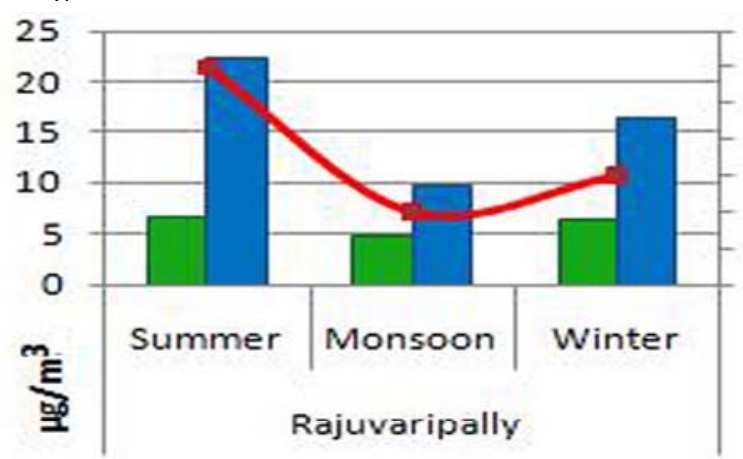

o ? 홍
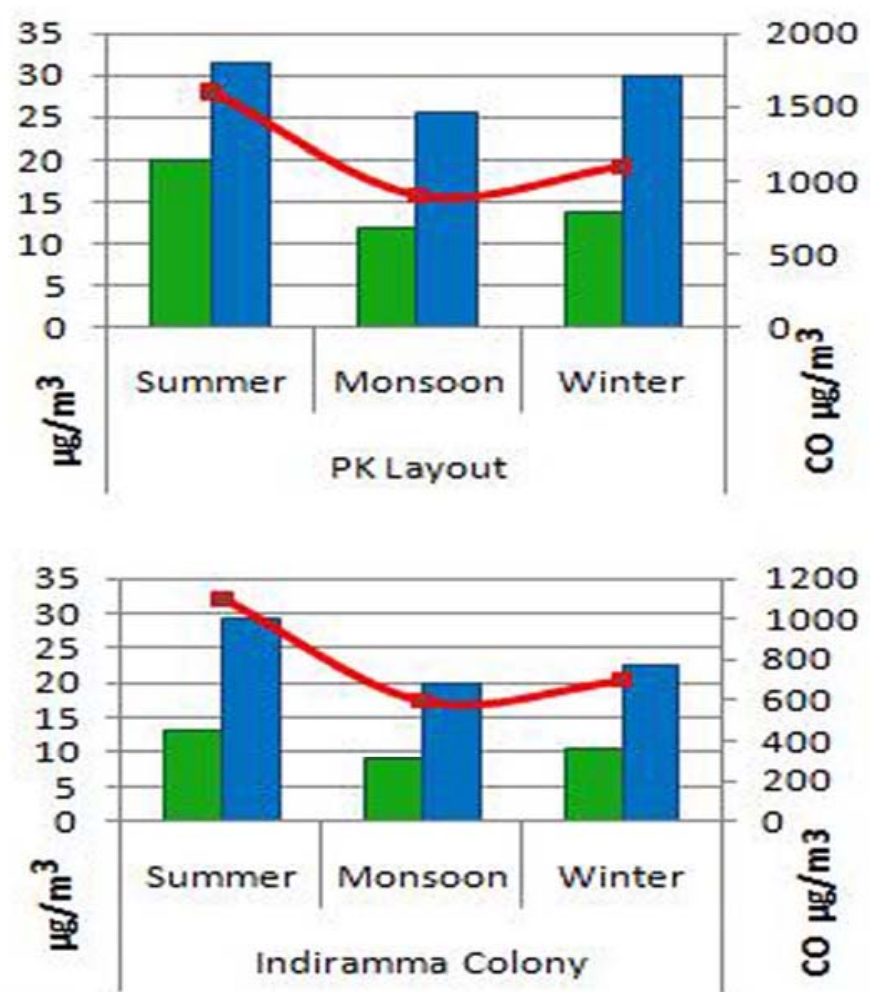

$\mathrm{\mu g} / \mathrm{m}^{3}$

$\mathrm{NO}_{\times} \mu \mathrm{g} / \mathrm{m}^{3}$

$\mathrm{CO} / \mathrm{m}^{3}$

areas, burning of agricultural wastes, availability of large quantities of dry firewood conducive for easy combustion for domestic purposes prominently in rural and slum areas, brick burning in kilns, large-scale stone breaking in quarries, captive as well as domestic power generation and increased industrial and construction activities due to favourable weather conditions. Moreover, especially during May-June, it is sultry with a low rate of evaporation. These conditions, along with lower turbulence, calm and stable atmosphere, decrease the ventilation coefficient of air, consequently triggering the agglomeration of pollutants in the ambient air.

Again, during September-October, the annual festivities of Lord Venkateswara, known as "Brahmotsavam" take place, that coincide with Dusserah 
Table 8. Coefficients of correlation between pollutant concentrations and meteorological parameters- Seasonal variation

\begin{tabular}{|c|c|c|c|c|c|c|c|c|c|c|c|c|}
\hline \multirow{2}{*}{$r$} & \multicolumn{3}{|c|}{ Temperature } & \multicolumn{3}{c|}{ Humidity } & \multicolumn{3}{c|}{ Rainfall } & \multicolumn{3}{c|}{ Wind Velocity } \\
\cline { 2 - 14 } & $\mathrm{S}$ & $\mathrm{M}$ & $\mathrm{W}$ & $\mathrm{S}$ & $\mathrm{M}$ & $\mathrm{W}$ & $\mathrm{S}$ & $\mathrm{M}$ & $\mathrm{W}$ & $\mathrm{S}$ & $\mathrm{M}$ & $\mathrm{W}$ \\
\hline $\mathrm{SO}_{2}$ & 0.710 & 0.340 & -0.183 & -0.674 & -0.266 & 0.697 & -0.095 & -0.115 & -0.003 & 0.805 & 0.158 & -0.002 \\
\hline $\mathrm{NOx}$ & 0.638 & 0.118 & 0.213 & -0.774 & 0.043 & 0.284 & -0.043 & -0.028 & 0.213 & 0.554 & -0.089 & -0.418 \\
\hline $\mathrm{CO}$ & 0.881 & 0.765 & -0.264 & -0.592 & -0.786 & 0.202 & -0.085 & -0.516 & -0.01 & 0.805 & -0.69 & -0.229 \\
\hline $\mathrm{SPM}$ & 0.351 & 0.823 & -0.394 & -0.65 & -0.768 & -0.148 & -0.052 & -0.669 & -0.509 & 0.173 & -0.805 & -0.172 \\
\hline $\mathrm{PM} 10$ & 0.239 & 0.612 & -0.288 & -0.306 & -0.508 & 0.203 & -0.086 & -0.346 & -0.084 & -0.004 & -0.553 & -0.464 \\
\hline
\end{tabular}

Note: S:Summer (March-May), M:Monsoon (July-September), W:Winter (November-January).

festival vacation. During these auspicious days, people from every nook and corner of the country throng the Seven hills via Tirupati. As September marks the withdrawal phase of the South-West monsoons and October being the transition period from monsoon to winter, stable atmospheric conditions prevail with less turbulence and mixing of air, resulting in a hike in the pollutant concentrations.

The period November-December, though classified as winter, receives more of rainfall due to cyclonic formations in the Bay of Bengal and from the North-East monsoons, resulting in further decrease of pollutant conglomeration due to scavenging action of rain water. Though there was a transitory and temporary increase in pollutant levels during the festive time of Diwali due to the extensive burning of fire crackers, releasing a large quantity of toxic gases into the atmosphere, there was still a reduction in the pollutant concentrations during winter in some instances, that effected the entire winter-time observations. But on the whole, winter concentrations of pollutants were greater than those recorded during monsoon, but lesser than the summer observations.

The months of January and February signify the effective winter period in Tirupati, with March being the period of transition between winter and summer. But, during Sankranti festive period in January, the pilgrim rush to Tirumala again picks up. This period also marks the resumption of all the activities mentioned above like brick-making, etc after their temporary suspension during the earlier months due to inclement climatic conditions. Also, Sankranti is the time of harvest. A lot of agricultural and other organic wastes are burnt after harvest with subsequent release of pollutants into air.

Taking into account the above phenomena, one can reach a conclusion that in addition to the local factors, the meteorological variables also play a vital and decisive role in the levels of air pollutants. Now, we examine the meteorological dependence of pollutant concentrations below.

Relation of air pollutants with meteorological parameters

The meteorological parameters like temperature, relative humidity, rainfall and wind velocity influence the concentration of air pollutants. Table 8 shows Coefficients of correlation between Pollutant Concentrations and Meteorological parameters calculated for the period of 2009 and 2010 in Tirupati region.

The temperature in Tirupati region during this period varied from $11^{\circ} \mathrm{C}$ (December) to $43^{\circ} \mathrm{C}$ (May). The relative humidity varied between $58.7 \%$ (June) to $89.1 \%$ (December). The quantity of total monthly rainfall reached a maximum of $175.8 \mathrm{~mm}$ (November). The average wind speed was of the order of $1.1 \mathrm{~m} / \mathrm{s}$ (October-November) to $3.5 \mathrm{~m} / \mathrm{s}$ (June-July).

\section{Variation with temperature}

A significant relation was observed between temperature and pollutants. The variation of pollutant concentrations with temperature is depicted graphically in Fig.6. All pollutants showed a significant, positive

Fig. 6. Relation between Temperature and Pollutants.
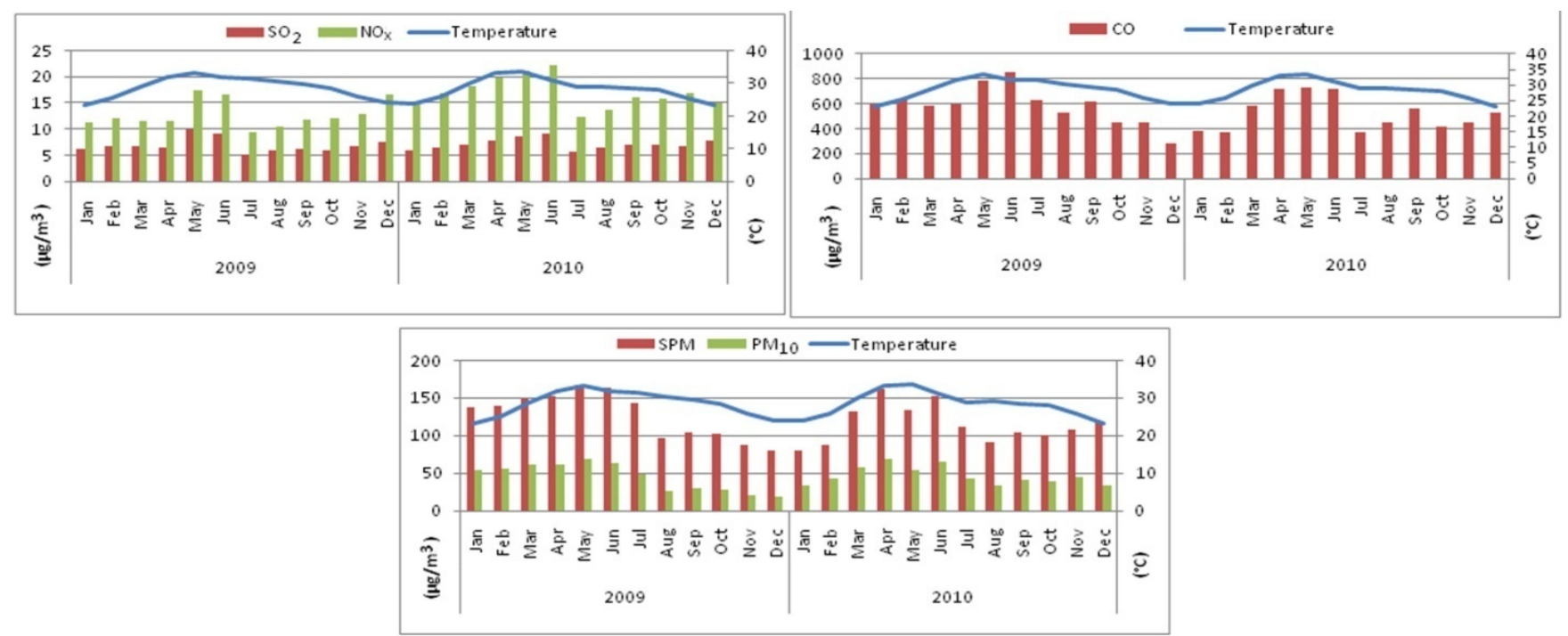

Research article

CIndian Society for Education and Environment (iSee)
"Air quality of Tirupati" http://www.indjst.org
Vanadeep \& Krishnaiah Indian J.Sci.Technol. 
Fig. 7. Effect of Relative Humidity (RH) on pollutants.

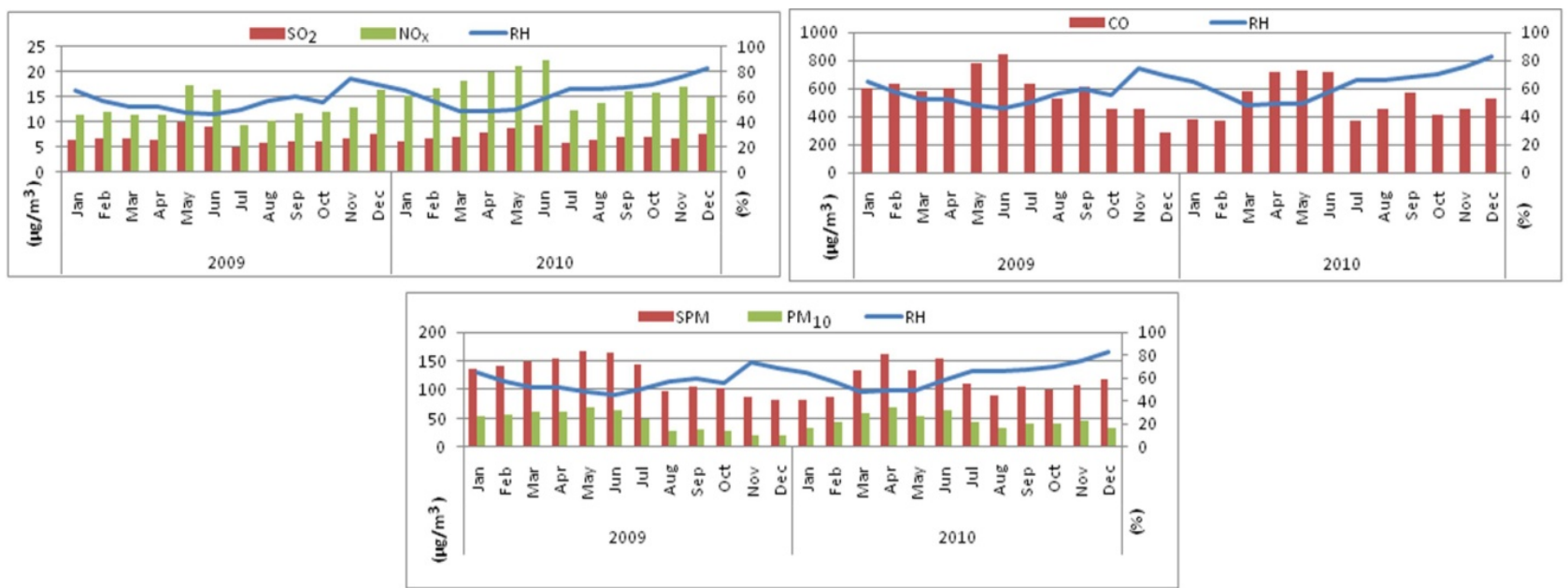

Fig. 8. Influence of Rainfall on pollutants
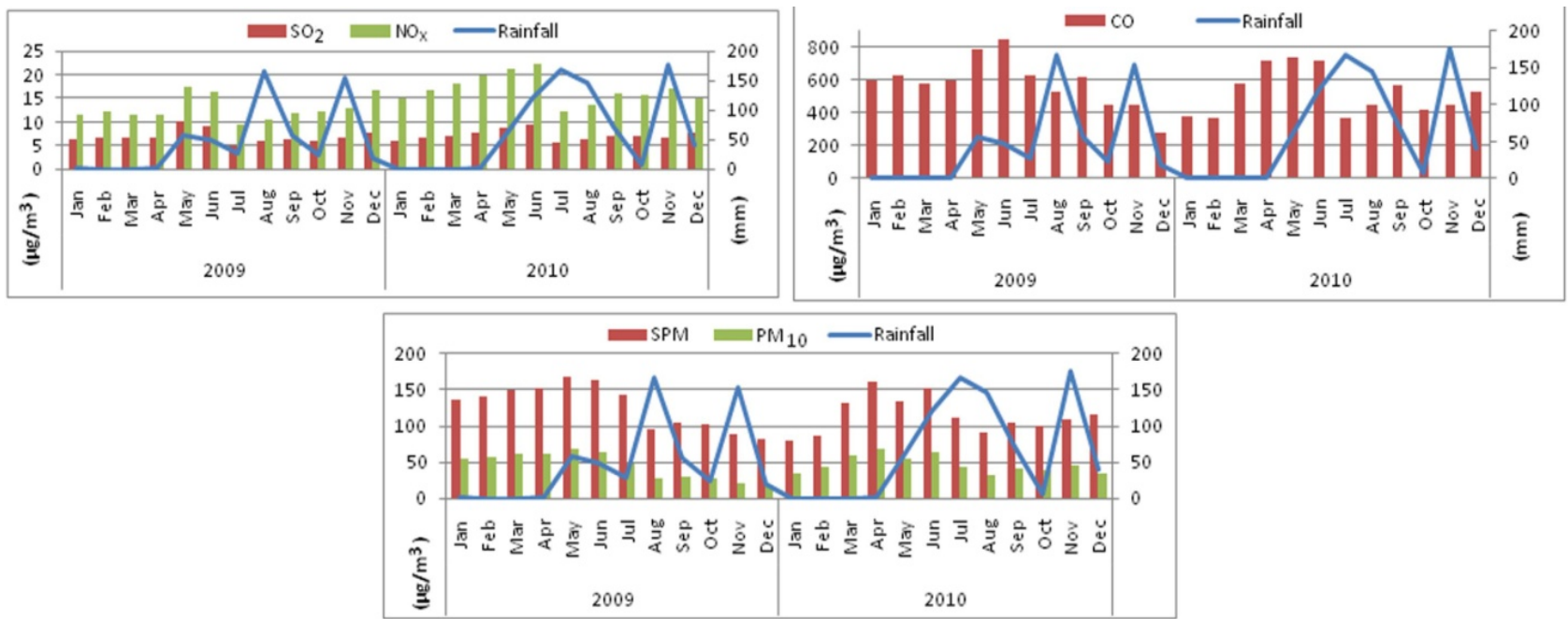

relationship with temperature during summer, with $\mathrm{CO}$ showing the greatest affinity. Temperature witnessed a positive correlation with all the pollutants during monsoon. This phenomenon can be attributed to the fact that generally, the temperatures during monsoon are predominantly on the lower side while scavenging of air takes place, minimizing the pollutant concentrations. On the other hand, if there is an increase in temperature during this season, then that indicates a period of dry spell in between episodes of precipitation. Hence, absence of rain promotes a surge in temperatures and thereby, lack of cleaning action in atmosphere. This facilitates the agglomeration of pollutants. During winter, a considerably strong and negative association was established in case of SPM and $\mathrm{PM}_{10}$, closely followed by $\mathrm{CO}$ as rise in temperature gives way to more effective mixing of air and consequent decline in the pollutant levels. During this period, $\mathrm{SO}_{2}, \mathrm{NO}_{\mathbf{x}}$ and $\mathrm{PM}_{10}$ presented relatively weaker correlations with temperature, suggesting that they depend largely on the extent of their emission from their sources, mainly automobiles and industries. CO showed the greatest attachment to temperature, followed by SPM.

Effect of relative humidity

All pollutants showed an inverse relation with relative humidity. The effect of relative humidity $(\mathrm{RH})$ on pollutant concentrations has been illustrated graphically in Fig. 7. This was very high during summer. The gaseous pollutants showed a relatively strong negative association than the particulates in summer. During monsoon, CO established a strong inverse relation, followed by SPM. $\mathrm{SO}_{2}$ showed a comparatively low correlation. $\mathrm{NO}_{\mathrm{x}}$ exhibited a very low positive correlation during this period. SPM was significantly negatively correlated with relative humidity during summer as the maximum concentration of SPM was observed when the moisture content of the atmosphere was low. This is because the cleaning process of the water droplets present in air had a crucial role in the sedimentation and removal of particulates, particularly the larger ones. Hence the $\mathrm{PM}_{10}$ particulates were in relatively low affinity with relative humidity. In winter all the pollutants, except SPM, were
Research article "Air quality of Tirupati"

CIndian Society for Education and Environment (iSee)
"Air quality of Tirupati"
http://www.indjst.org
Vanadeep \& Krishnaiah Indian J.Sci.Technol. 
moderately positively related to R.H. This might be due to the existence of an inversion layer in the atmosphere that prevents effective mixing of the lower air with the upper layers of air. $\mathrm{NO}_{\mathrm{x}}, \mathrm{CO}$ and $\mathrm{PM}_{10}$ exhibited an ordinary positive correlation with relative humidity. $\mathrm{SO}_{2}$ was found to possess the maximum positive correlation with R.H. during winter. SPM was slightly inversely associated as the cleansing action of water droplets in air is mainly predominant on larger particulates. Overall, $\mathrm{NO}_{\mathrm{x}}$ and $\mathrm{PM}_{10}$ were found to be comparatively less affected by R.H. as is evident from the correlation coefficient values. Influence of rainfall

All the pollutants showed an overall negative association with the quantity of rainfall. Graphical portrayal of influence of rainfall on pollutant concentrations reveals that this relation was weak during summer and strong during monsoon, when compared to non-monsoon period.(Fig.8). In summer, all pollutants showed a very weak relation with rainfall. Even during monsoon, $\mathrm{NO}_{x}$ and $\mathrm{SO}_{2}$ showed an insignificant relation, with $\mathrm{NO}_{x}$ exhibiting a particularly low correlation. SPM showed the greatest correlation during this period, followed by $\mathrm{CO}$ and $\mathrm{PM}_{10}$. Especially the scavenging action of rain water is prominent in case of particulates owing to its coagulative action and the consequent settling process that follows. The winter rainfall had very little impact on $\mathrm{SO}_{2}$ and $\mathrm{CO}$ concentrations. The ambient concentration of $\mathrm{NO}_{x}$ increased during winter, indicating that it's relation with rainfall is nominal. The large particulates of SPM were predominantly affected during episodes of winter precipitation owing to the cleansing mechanism. During the same period, considerably lesser negative correlation was seen between rainfall and $\mathrm{PM}_{10}$ concentrations. relationship with wind velocity during summer, except $\mathrm{PM}_{10}$. $\mathrm{PM}_{10}$ was not found to be well correlated with wind velocity during this period (Fig.9). Generally, high wind speeds facilitate effective mixing in atmosphere, thereby resulting in the dilution of pollutant concentrations. But, during summer, pollutant levels were found to be the highest. This is also arguably that period of the year when the wind speeds are high. Generally in summer, the extremely hot and dry winds from arid and semi-arid regions like Rajasthan, Madhya Pradesh and southern parts of Uttar Pradesh are prevalent over south peninsular India, escalating the scorching temperatures. As a result of the soaring heat, loss of moisture occurs from air and soil. This decreases the relative humidity. This, in conjunction with the local anthropogenic factors, this contributes to the high pollutant concentrations. During monsoon, a noticeable negative association was established with SPM, $\mathrm{PM}_{10}$ and $\mathrm{CO}$ owing to the dual action of scavenging by rain water and dispersion of pollutants by the prevailing winds. $\mathrm{NO}_{x}$ and $\mathrm{SO}_{2}$ were not significantly correlated to wind velocity, with $\mathrm{SO}_{2}$ showing a slight positive correlation and $\mathrm{NO}_{\times}$confined to a weak negative correlation. In winter, all the pollutants were inversely correlated to wind velocity to some extent or the other, with $\mathrm{SO}_{2}$ engaged in almost ignorable negative association. The deterioration in pollutant levels in winter during episodes of increased wind velocity results from the fact that high wind speeds disturb the calm and stable weather conditions accompanied by the formation of an inversion layer, causing turbulence and subsequent mixing. $\mathrm{PM}_{10}$ was identified to possess a stronger inverse correlation as compared to SPM, portraying the fact that SPM is emitted from relatively far off sources and transported across a distance, while $\mathrm{PM}_{10}$ originates from

Fig. 9. Impact of Wind Velocity on pollutants.
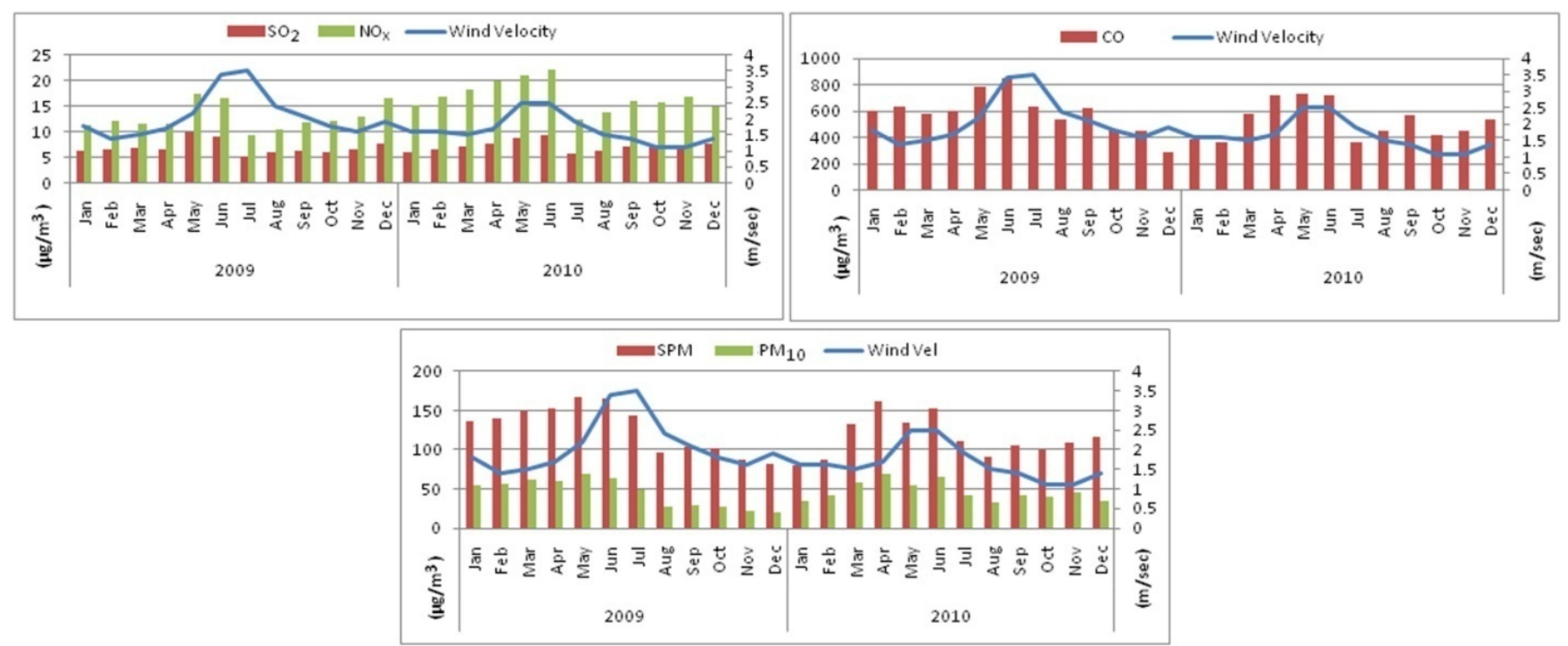

Impact of wind velocity

The impact of wind velocity on pollutant concentrations is significant. Almost all pollutants presented a positive Research article

CIndian Society for Education and Environment (iSee) 


\section{Correlation between pollutants}

Table 9. Coefficients of correlation between pollutants in Tirupati Region

\begin{tabular}{|l|l|l|l|l|}
\hline Pollutants & $\mathrm{NOx}$ & $\mathrm{CO}$ & $\mathrm{SPM}$ & $\mathrm{PM}_{10}$ \\
\hline $\mathrm{SO}_{2}$ & 0.761 & 0.582 & 0.506 & 0.51 \\
\hline $\mathrm{NOx}$ & $\ldots .$. & 0.261 & 0.194 & 0.367 \\
\hline $\mathrm{CO}$ & $\ldots .$. & $\ldots .$. & 0.869 & 0.753 \\
\hline $\mathrm{SPM}$ & $\ldots .$. & $\ldots .$. & $\ldots .$. & 0.916 \\
\hline
\end{tabular}

Table 10. Area wise seasonal variation of coefficients of correlation among pollutants in Tirupati

\begin{tabular}{|c|c|c|c|c|c|c|c|c|c|c|c|c|c|}
\hline \multirow{2}{*}{ Location } & & \multicolumn{4}{|c|}{ Summer } & \multicolumn{4}{|c|}{ Monsoon } & \multicolumn{4}{|c|}{ Winter } \\
\hline & & NOx & $\mathrm{CO}$ & SPM & $\mathrm{PM}_{10}$ & NOx & $\mathrm{CO}$ & SPM & $\mathrm{PM}_{10}$ & NOx & $\mathrm{CO}$ & SPM & $\mathrm{PM}_{10}$ \\
\hline \multirow{4}{*}{$\begin{array}{l}\text { Railway } \\
\text { Colony }\end{array}$} & $\mathrm{SO}_{2}$ & 0.576 & 0.219 & 0.583 & 0.623 & 0.909 & 0.606 & 0.786 & 0.723 & 0.954 & -0.295 & 0.406 & -0.039 \\
\hline & NOx & & 0.205 & 0.033 & 0.806 & 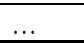 & 0.403 & 0.793 & 0.63 & & -0.509 & 0.197 & -0.031 \\
\hline & $\mathrm{CO}$ & $\ldots$ & $\ldots$ & 0 & 0.101 & $\ldots$ & ... & 0.548 & 0.423 & $\ldots$ & $\ldots$ & 0.722 & 0.491 \\
\hline & SPM & & & & 0.562 & - & & & 0.714 & & & & 0.591 \\
\hline \multirow{4}{*}{$\begin{array}{l}\text { Ram Nagar } \\
\text { Quarters }\end{array}$} & $\mathrm{SO}_{2}$ & -0.034 & 0.97 & 0.692 & 0.376 & 0.879 & 0.543 & 0.701 & 0.643 & 0.55 & -0.209 & 0.119 & -0.372 \\
\hline & $\mathrm{NOx}$ & & -0.214 & 0.085 & 0.15 & $\ldots$ & 0.318 & 0.625 & 0.67 & & -0.17 & 0.294 & 0.051 \\
\hline & $\mathrm{CO}$ & & 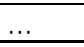 & 0.697 & 0.335 & $\ldots$ & & 0.673 & 0.398 & & $\ldots$ & 0.481 & 0.433 \\
\hline & SPM & & & & 0.896 & $\ldots$ & & & 0.8 & & & $\cdots$ & 0.866 \\
\hline \multirow{4}{*}{ Gandhipuram } & $\mathrm{SO}_{2}$ & 0.133 & 0.707 & 0.315 & 0.337 & 0.561 & 0.262 & 0.556 & 0.811 & 0.454 & 0.206 & 0.128 & 0.211 \\
\hline & $\mathrm{NOx}$ & $\cdots$ & 0.707 & -0.568 & -0.532 & $\ldots$ & 0.668 & 0.006 & 0.43 & $\cdots$ & 0.579 & 0.117 & 0.334 \\
\hline & $\mathrm{CO}$ & $\ldots$ & $\ldots$ & 0.063 & 0.04 & $\ldots$ & & 0.174 & 0.371 & $\ldots$ & $\ldots$ & 0.622 & 0.766 \\
\hline & SPM & & & & 0.954 & & & & 0.855 & & & & 0.431 \\
\hline \multirow{4}{*}{$\begin{array}{l}\text { Indiramma } \\
\text { Colony }\end{array}$} & $\mathrm{SO}_{2}$ & 0.732 & 0.533 & 0.738 & 0.154 & 0.888 & 0.711 & 0.671 & 0.718 & 0.621 & 0.406 & 0.496 & -0.528 \\
\hline & $\mathrm{NOx}$ & $\ldots$ & 0.951 & 0.627 & 0.043 & $\ldots$ & 0.415 & 0.524 & 0.741 & $\cdots$ & -0.012 & 0.468 & -0.34 \\
\hline & $\mathrm{CO}$ & $\ldots$ & $\ldots$ & 0.629 & 0.138 & $\ldots$ & $\ldots$ & 0.567 & 0.347 & $\ldots$ & $\ldots$ & 0.776 & 0.249 \\
\hline & SPM & & & & 0.557 & & & & 0.913 & & & & 0.386 \\
\hline \multirow{4}{*}{ Rajuvaripally } & $\mathrm{SO}_{2}$ & 0.07 & 0.569 & 0.776 & 0.293 & 0.676 & 0.585 & 0.404 & 0.402 & 0.198 & -0.675 & -0.163 & -0.061 \\
\hline & $\mathrm{NOx}$ & $\ldots$ & 0.765 & 0.532 & 0.778 & $\ldots$ & 0.614 & 0.628 & 0.79 & $\ldots$ & 0.552 & 0.301 & 0.506 \\
\hline & $\mathrm{CO}$ & & & 0.804 & 0.717 & - & & 0.931 & 0.702 & & & 0.132 & 0.231 \\
\hline & SPM & & & & 0.827 & & & & 0.859 & & & & 0.901 \\
\hline \multirow{4}{*}{ PK Layout } & $\mathrm{SO}_{2}$ & 0.96 & 0.545 & -0.335 & -0.335 & 0.92 & 0.683 & 0.507 & 0.54 & 0.225 & 0.069 & -0.234 & -0.327 \\
\hline & NOx & & 0.481 & -0.236 & $\begin{array}{l}-0.2 \\
\end{array}$ & $\cdots$ & 0.521 & 0.445 & 0.452 & & -0.62 & -0.595 & -0.684 \\
\hline & $\mathrm{CO}$ & 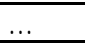 & & 0.327 & 0.205 & $\ldots$ & & 0.866 & 0.922 & & & 0.77 & 0.647 \\
\hline & SPM & & & & 0.971 & $\ldots$ & & & 0.985 & & & & 0.865 \\
\hline
\end{tabular}

From a glance at the correlation values, it can be easily observed that pollutants are significantly and positively related to each other (Tables 9-11). This represents the combined effect of the different pollutant concentrations in six areas during a period of two years. $\mathrm{SO}_{2}$ was in good agreement with all other pollutants, especially with $\mathrm{NO}_{\mathrm{X}}$, suggesting that they had some common sources of emission like heavy vehicles (mainly diesel vehicles), industries, etc. $\mathrm{NO}_{x}$ was particularly in good conjunction with $\mathrm{PM}_{10}$, followed by $\mathrm{CO}$, indicating that they share the same source, viz., automobiles. Besides vehicular emissions, $\mathrm{CO}$ also has other principal sources like burning of firewood for domestic purposes, burning of agricultural wastes, etc. This leads to a situation where $\mathrm{CO}$ concentrations go hand-in-hand with SPM and $\mathrm{PM}_{10}$ concentrations. Further from the study, it was also observed that, to a great extent, $\mathrm{PM}_{10}$ and SPM followed almost a similar trend throughout the year with respect to each other, accounting for a very high degree of correlation between them.

\section{Conclusion}

The fluctuation in pollutant concentrations are in good agreement with the annual seasonal pattern. The 
$\mathrm{CO}$ is many times more fatal than the open-air exposure. Rajuvaripally is situated near a stone-breaking quarry.

Occasional and periodical agricultural waste burning also takes place. These factors influence the ambient air and pose a health risk to the inhabitants of this area. Railway colony seems to be free from significant effects of pollution as it is located away from the main road and due to absence of any of the conditions mentioned above. Occasional increase of SPM concentrations has been observed, strengthening the claim that they originate from distant sources and can be transported with prevailing winds. However, they were well within their prescribed limits and were not expected to cast their impact on human health. All these prove that the local anthropogenic factors immensely influence the ambient air quality.

Table 11. Area wise variation of coefficients of correlation among pollutants in Tirupati

\begin{tabular}{|c|c|c|c|c|c|}
\hline Location & Pollutants & NOx & $\mathrm{CO}$ & SPM & $\mathrm{PM}_{10}$ \\
\hline \multirow{4}{*}{$\begin{array}{l}\text { Railway } \\
\text { Colony }\end{array}$} & $\mathrm{SO}_{2}$ & 0.647 & 0.276 & 0.555 & 0.473 \\
\hline & NOx & $\ldots$ & -0.057 & 0.201 & 0.252 \\
\hline & $\mathrm{CO}$ & $\ldots$ & $\ldots$ & 0.569 & 0.383 \\
\hline & SPM & $\ldots$ & $\ldots$ & $\ldots$ & 0.633 \\
\hline \multirow{4}{*}{$\begin{array}{l}\text { Ram Nagar } \\
\text { Quarters }\end{array}$} & $\mathrm{SO}_{2}$ & 0.442 & 0.531 & 0.634 & 0.4 \\
\hline & NOx & $\ldots$ & -0.044 & 0.28 & 0.319 \\
\hline & $\mathrm{CO}$ & $\ldots$ & $\ldots$ & 0.642 & 0.433 \\
\hline & SPM & $\ldots$ & $\ldots$ & $\ldots$ & 0.841 \\
\hline \multirow{4}{*}{ Gandhipuram } & $\mathrm{SO}_{2}$ & 0.364 & 0.479 & 0.518 & 0.596 \\
\hline & NOx & $\ldots$ & 0.613 & -0.021 & 0.215 \\
\hline & $\mathrm{CO}$ & $\ldots$ & $\ldots$ & 0.529 & 0.627 \\
\hline & SPM & $\ldots$ & $\ldots$ & $\ldots$ & 0.945 \\
\hline \multirow{4}{*}{$\begin{array}{l}\text { Indiramma } \\
\text { Colony }\end{array}$} & $\mathrm{SO}_{2}$ & 0.813 & 0.562 & 0.629 & 0.35 \\
\hline & NOx & $\ldots$ & 0.439 & 0.531 & 0.356 \\
\hline & $\mathrm{CO}$ & $\ldots$ & $\ldots$ & 0.715 & 0.384 \\
\hline & SPM & $\ldots$ & $\ldots$ & $\ldots$ & 0.54 \\
\hline \multirow{4}{*}{ Rajuvaripally } & $\mathrm{SO}_{2}$ & 0.276 & 0.362 & 0.186 & 0.123 \\
\hline & NOx & $\ldots$ & 0.5 & 0.605 & 0.621 \\
\hline & $\mathrm{CO}$ & $\ldots$ & $\ldots$ & 0.686 & 0.57 \\
\hline & SPM & $\ldots$ & $\ldots$ & $\ldots$ & 0.841 \\
\hline \multirow{4}{*}{ PK Layout } & $\mathrm{SO}_{2}$ & 0.808 & 0.505 & 0.313 & 0.319 \\
\hline & NOx & $\ldots$ & 0.244 & 0.128 & 0.165 \\
\hline & $\mathrm{CO}$ & $\ldots$ & $\ldots$ & 0.896 & 0.863 \\
\hline & SPM & $\ldots$ & $\ldots$ & $\ldots$ & 0.934 \\
\hline
\end{tabular}

The hot and dry winds blowing from the arid North and North West regions of India over the semi-arid region of Tirupati during summer, contribute to the loss of moisture and to the rise in pollutant concentrations during the season. Pollutants had an appreciable level of correlation with meteorological variables, namely, temperature, relative humidity, rainfall and wind velocity. From this, one can easily infer that local factors and meteorological constraints, in tandem, influence the levels of pollution in a given area. Further, the following remedies need to be enforced to lighten the hefty burden of pollution borne by the atmosphere:
- Clean and sophisticated technologies should be relied upon for use in automobiles and other industries and this must be made mandatory throughout the country, even in small cities and towns.

- Old and antiquated vehicles should be abandoned in phases as they emit pollutants in excess.

- The BHARAT stage emission standards must be enforced and stringently implemented.

- The spirit of the United Nations Climate Change Conference in Copenhagen (COP-15, Dec. 7-18, 2009) need to be carried on. The "Carbon-Credit" system must be widely and efficiently implemented without any discriminations and discrepancies. Most importantly, India must ensure that it delivers on its proposed action plan of "20\%-25\% cut in Carbon emission intensities below 2005 levels by the year 2020".

- The government, in collaboration with the private sector should provide incentives and endorsements for the production, promotion and marketing of such 'environment-friendly' machinery. On the other hand, steps ought to be initiated to facilitate Research and Development of more cost-effective and economic ecosensitive technologies.

- Adequate green cover should be created in and around the town to improve the air-quality.

All these goals, when realised, would act as beacon lights in the voyage of mankind in their undaunted mission with indomitable spirit to conquer the imminent perils of environmental degradation and to accomplish the timetested dream of a "Green Planet".

\section{Acknowledgement}

The authors convey their heartfelt thankfulness to Sri Laxmi Kant Reddy, Sri Jitender Reddy, Sri Vijay Reddy and other associate staff of Vison Labs, Hyderabad for providing all the equipment required for carrying out the present study and for their services in analysing the collected air samples. We are sincerely indebted to Prof. Sreenivasulu Reddy and Prof. Sumati of Sri Venkateswara Agricultural College, Tirupati for giving us access to the requested meteorological data, essential for carrying out this study. We express our profound gratefulness and appreciation to Ms. Haripriya Chinthapally, USA for her invaluable support and cooperation in statistical data programming as well as in formatting the article.

\section{References}

1. Agarwal R, Jayaraman G, Anand S and Marimuthu P (2006) Assessing respiratory morbidity through pollution status and meteorological conditions for delhi. Environ. Monitoring \& Asses. 114, 489-504.

2. Anderson KR, Avol EL, Edwards SA, Shamoo DA, Pen RC, Linn WS and Hackney JD (1992) Controlled exposure of volunteers to respirable carbon and sulphuric acid aerosols. J. Air Waste Manage. Assoc. 42, 770-776.

3. Brandon C., Hommann K. (1995) The Cost Of Inaction: Valuing The Economy-Wide Cost Of Environmental Degradation In India; paper presented at the 'Modelling Global Sustainability' conference held in United Nations University,Tokyo,October, 1995.

4. Bridgman HA, Davies TD, Jickells T, Hunova I, Tovey K, Bridges $\mathrm{K}$ and Surapipith $\mathrm{V}$ (2002) Air pollution in the krusne hory region, czech republic during the 1990s. Atmospheric Environ. 36, 3375-3389.

5. Cacciola RR, Sarva M and Polosa R (2002) Adverse respiratory effects and allergic susceptibility in relation to
Research article

CIndian Society for Education and Environment (iSee)
"Air quality of Tirupati"

http://www.indjst.org
Vanadeep \& Krishnaiah Indian J.Sci.Technol. 
particulate air pollution. Flirting With Disaster. Allergy. 57, 281286.

6. Chan LY and Kwok WS (2001) Roadside suspended particulates at heavily trafficked urban sites of Hong Kong seasonal variation and dependence on meteorological conditions. Atmospheric Environ. 35, 3177-3182.

7. Chandra Mouli P, Venkata Mohan S and Jayarama Reddy S (2003) A study on major inorganic ion composition of atmospheric aerosols at Tirupati. J. Hazardous Materials. B96, 217-228.

8. Chandra Mouli P, Venkata Mohan S and Jayarama Reddy S (2005) Assessment of microbial (Bacteria) concentrations of ambient air at semi-arid urban region: Influence of meteorological factors. Applied Ecol. \& Environ. Res. 3(2), 139-149.

9. Comrie AC (1996) An all-season synoptic climatology of air pollution in the US-Mexico border. Sci. Total Environ. 276, 4968.

10. CPCB, Central Pollution Control Board, New Delhi, National ambient air quality standards, published in the gazette of India vide extraordinary notification No(s). S.O.384 (E), dated $11^{\text {th }}$ April, 1994 and S.O. 935(E), dated $14^{\text {th }}$ October, 1998.

11. Demirci E and Cuhadaroglu B (2000) Statistical analysis of wind circulation and air pollution in urban trabzon. Energy \& Buildings. 31, 49-53.

12. Department of Transport, UK (2002) Sources of particulate matter in urban areas: TRAMAQ Project UG 250.

13. Dockery DW and Pope CA (1994) Acute respiratory effects of particulate air pollution. Annu. Rev. Publ. Health. 15, 107-132.

14. Dockery DW, Pope III CA, Xu X, Spengler JD, Ware JH, Fay ME, Ferris BG and Speizer FE (1993) An association between air pollution and mortality in six US cities. New Engl. J. Med. 329, 1573-1759.

15. Economopoulou AA and Economopoulos AP (2002) Air pollution in athens basin and health risk assessment. Environ. Monitoring \& Asses. 80, 277-299.

16. Gadhavi H and Jayaraman A (2010) Absorbing aerosols: contribution of bio mass burning and implications for radiative forcing. Annales Geophysicae. 28, 103-111.

17. Glovsky MM, Miguel AG and Cass GR (1997) Particulate air pollution: Possible relevance in asthma. Allergy \& Asthma Proc. 18, 163-166.

18. Gupta AK, Patil RS and Gupta SK (2003) Statistical analysis of particulate data sets for jawahar lal Nehru and surrounding harbor region in india. Environ. Monitoring \& Asses. 95, 295309 .

19. Hedin LO, Granat L, Likens GE, Buishand TA, Galloway JN, Butler TJ and Rodhe H (1994) Steep declines in atmospheric base cations in regions of Europe and North America. Nature. 367, 351-354.

20. International Agency of Research on Cancer (IARC) (1989) Diesel and gasoline engine exhausts and some nitroarenes. IARC Monograph Evaluation of Carcinogenic Risks to Humans. 46, 41.

21. Jacobson MZ (2001) Strong radiative heating due to the mixing state of black carbon in atmospheric aerosols. Nature. 409, 695-697.

22. Kukkonen J, Konttinen M, Bremer $P$, Salmi $T$ and Saari $H$ (2000) The seasonal variation of urban air quality in northern european conditions. Intl. J. Environ. \& Pollution. 14, 1-6.

23. Lee CG, Yuan CS, Chang JC and Yuan C (2005) Effects of aerosol species on atmospheric visibility in kaohsiung city, Taiwan. J.Air \& Waste Management. Assoc.55,1031-1041.
Vol. 4 No. 11 (Nov 2011)

ISSN: 0974- 6846
24. Mayer H (1999) Air pollution in cities. Atmos. Environ. 33, 4029-4037.

25. Monn C, Braendli O, Schaeppi C, Ackermann-Liebrich $U$ and Leuenberger $P$ (1995) Particulate matter $10 \mu \mathrm{m}\left(\mathrm{PM}_{10}\right)$ and total suspended particulates (TSP) in Urban, Rural and alpine air in Switzerland. Atmospheric Environ. 29, 2565-2573.

26. Nanda Kumar NV, Sreedhar Babu P, Rajasekhar M and Nagarjuna A (2008) Air pollution levels in tirupati and its relation to meteorological factors. Ecoscan. 2(2), 241-253

27. Pope CA, Burnett RT, Thun MJ, Calle EE, Krewski D, Ito K, Thurston GD (2002) Lung cancer, cardiopulmonary mortality and long-term exposure to fine particulate air pollution. JAMAJ. Am. Med. Assoc. 287, 1132-1141.

28. Qin G and Huang M (2001) A study on rain water acidification processes in ten cities of china. Water, Air \& Soil Pollu. 130, 163-174.

29. Safai PD, Rao PS, Momin GA, Ali K, Chate DM and Praveen PS (2004) Some observations on the characteristics of aerosols at traffic junctions in Pune City. Indian J. Radio \& Space Phys. 33, 260-266.

30. Sandradewi J (2008) A study of wood burning versus traffic aerosols using a multi-wavelength aethalometer, Doctor of Sciences (Ph.D) dissertation. ETH ZUR/CH, Zurich, Switzerland. Diss. ETH No. 17694

31. Shendell DG and Naeher LP (2002) A pilot study to assess ground-level ambient air concentration of fine particles and carbon monoxide in Urban Guatemala. Environ. Intl. 28, 375382.

32. Streets DG, Tsai NY, Akimoto $H$ and Oka K (2001) Trends in emissions of acidifying species in asia. Water, Air \& Soil Pollu. 130, 187-192.

33. Wang G, Wang H, Yu Y, Gao S, Feng J, Gao S and Wang L (2003) Chemical characterization of water-soluble components of $\mathrm{PM}_{10}$ and $\mathrm{PM}_{2.5}$ atmospheric aerosols in five locations of nanjing, China. Atmospheric Environ. 37, 28932902.

34. Wise EK and Comrie AC (2005) Extending the KZ filter: application to Ozone, particulate matter and meteorological trends. Atmospheric Environ. 39, 2969-2980.

35. World Health Organization (2000) Air Quality Guidelines for Europe; WHO Regional Publ; WHO Regional Office for Europe, Copenhagen; European Series No. 91.

36. Wrobel A, Rokita E and Maenhaut W (2000) Transport of traffic-related aerosols in urban areas. Sci. Total Environ. 257, 199-211.

37. Yang KL (2002) Spatial and seasonal variation of $\mathrm{PM}_{10}$ concentrations in Taiwan. Atmospheric Environ. 36, 34033411.

38. Ye SH, Jian Song WZ, Peng BC, Yuan D, Lu YM and Qi PP (1999) Toxicity and health effects of vehicle emissions in shanghai. Atmos Environ. (UK). 34, 419-429.

39. Yuan CS, Lee CG, Liu SH, Yuan C, Yang YH and Chang CJ (2006) Correlation of atmospheric visibility with chemical composition of kaohsiung aerosols. Atmos. Res. 82, 663-679.

40. Yuan CS, Lee CG, Liu SH, Yuan C, Yang YH and Chen CT (2002) Developing strategies for improving urban visual air quality. Aerosol Air Qual. Res. 2, 9-22.

41. Zhao D, Xiong J, Xu Y, Chan WH (1988) Acid rain in southwestern china. Atmos. Environ. 22, 349-358.
Research article

COIndian Society for Education and Environment (iSee)
"Air quality of Tirupati"

http://www.indjst.org
Vanadeep \& Krishnaiah Indian J.Sci.Technol. 